\title{
Sponge contribution to the silicon cycle of a diatom-rich shallow bay
}

1 María López-Acosta ${ }^{1 *}$, Manuel Maldonado ${ }^{2}$, Jacques Grall $^{3}$, Axel Ehrhold $^{4}$, Cèlia Sitjà ${ }^{2}$, Cristina

2 Galobart $^{2}$, Aude Leynaert ${ }^{5}$

$3{ }^{1}$ Oceanology Group, Instituto de Investigaciones Marinas (IIM-CSIC), C/ Eduardo Cabello 6, 36208

$4 \quad$ Vigo, Spain

$5 \quad{ }^{2}$ Department of Marine Ecology, Centro de Estudios Avanzados de Blanes (CEAB-CSIC), Acceso

6 Cala St. Francesc 14, Blanes 17300, Girona, Spain

$7 \quad{ }^{3}$ Observatoire des Sciences de l'Univers, UMS 3113, Institut Universitaire Européen de la Mer,

8 Technopôle Brest-Iroise, Plouzané 29280, France

$9{ }^{4}$ IFREMER, Géosciences Marines, Centre de Brest, BP70, CS10070, Plouzané 29280, France

$10{ }^{5}$ Laboratoire des Sciences de l'Environnement Marin, UMR 6539, Institut Universitaire Européen de

11 la Mer, Technopôle Brest-Iroise, Plouzané 29280, France

12 * Correspondence:

13 María López-Acosta

14 lopezacosta@iim.csic.es

15 Running title: Coastal silicon cycle through sponges

16 Keywords: silicon, silicifiers, sponges, coastal ocean, benthic-pelagic coupling 


\section{Abstract}

19 In coastal systems, planktonic and benthic silicifiers compete for the pool of dissolved silicon, a

20 nutrient required to make their skeletons. The contribution of planktonic diatoms to the cycling of

21 silicon in coastal systems is often well characterized, while that of benthic silicifiers such as sponges

22 has rarely been quantified. Herein, silicon fluxes and stocks are quantified for the sponge fauna in the

23 benthic communities of the Bay of Brest (France). A total of 45 siliceous sponge species living in the

24 Bay account for a silicon standing stock of 1215 tons, while that of diatoms is only 27 tons. The

25 silicon reservoir accumulated as sponge skeletons in the superficial sediments of the Bay rises to

261775 tons, while that of diatom skeletons is only 248 tons. These comparatively large stocks of

27 sponge silicon were estimated to cycle two orders of magnitude slower than the diatom stocks.

28 Sponge silicon stocks need years to decades to be renewed, while diatom turnover lasts only days.

29 Although the sponge monitoring over the last 6 years indicates no major changes of the sponge

30 stocks, our results do not allow to conclude if the silicon sponge budget of the Bay is at steady state,

31 and potential scenarios are discussed. The findings buttress the idea that sponges and diatoms play

32 contrasting roles in the marine silicon cycle. The budgets of these silicon major users need to be

33 integrated and their connections revealed, if we aim to reach a full understanding of the silicon

34 cycling in coastal ecosystems. 


\section{Introduction}

37 There is great interest in understanding the cycling of silicon $(\mathrm{Si})$ in marine environments because

38 this nutrient is key to the functioning of marine ecosystems. In coastal oceans, Si is responsible for

39 sustaining a large proportion of primary productivity and many of the food webs that ultimately

40 sustain fish and human populations (Kristiansen and Hoell 2002; Ragueneau et al. 2006). Shortage of

41 Si availability in coastal areas frequently reflects situations of ecosystem disequilibrium and

42 proliferation of harmful algal blooms (Davidson et al. 2014; Glibert and Burford 2017; Thorel et al.

43 2017). Thus, a thorough understanding of the cycling of Si in coastal marine environments is critical

44 for effective ecosystem management.

A substantial part of the Si cycling in the marine environment occurs through a variety of micro-

and macro-organisms, the silicifiers, which require Si to build their siliceous skeletons (DeMaster

2003; Tréguer et al. 2021). To date, our understanding of the biogeochemical cycling of Si in the

marine environment is based predominantly on the role of diatoms, microscopic unicellular

eukaryotic algae which are the most abundant silicifiers in the global ocean (Malviya et al. 2016;

50 Tréguer et al. 2021). Other silicifiers, such as siliceous Rhizaria and sponges, have received less

attention and, consequently, their role is largely dismissed in most budgets of the marine Si cycle. To

52 quantify the cycle contribution of siliceous sponges is particularly complicated given their benthic

53 nature and heterogeneous distribution across the depths of the world's oceans. However, there is

54 growing evidence that sponges are important contributors to the Si cycle in terms of Si standing

55 stocks and reservoirs (Maldonado et al. 2010, 2019).

In the present study, the Bay of Brest (France) was monitored to assess the relative contribution of

57 siliceous sponges to the Si budget of this emblematic coastal system. This Bay has been the subject

58 of numerous ecological, biogeochemical, and physical studies and is currently one of the best-studied 
coastal ecosystems in Europe, in terms of both structure and ecosystem functioning (Le Pape et al.

60 1996; Del Amo et al. 1997; Chauvaud et al. 2000; Ragueneau et al. 2018). In this ecosystem, diatoms

61 dominate the annual pelagic primary production (Quéguiner and Tréguer 1984; Del Amo et al. 1997).

62 Other planktonic silicifiers such as silicoflagellates, polycystines, and phaeodarians are rarely

63 recorded in the monthly surveys of the planktonic community of the Bay, and when found, they are

64 low abundant (https://www.phytobs.fr/). Silicic acid (dSi) concentrations vary over the year cycle

65 from below $1 \mu \mathrm{M}$ in spring and early summer up to $15-20 \mu \mathrm{M}$ in late autumn and winter. Therefore,

66 in this ecosystem diatom's activity is limited by dSi principally during spring and early summer

67 (Ragueneau et al. 2002), but sponges are limited all year round, as these organisms need dSi

68 concentrations of $100-200 \mu \mathrm{M}$ to reach their maximum speed of Si consumption $\left(\mathrm{K}_{\mathrm{M}}=30-100 \mu \mathrm{M}\right.$

69 Si; Reincke and Barthel 1997; Maldonado et al. 2011, 2020; López-Acosta et al. 2016, 2018).

70 In this system, both dredging and diving research activities have identified important populations

71 of siliceous sponges (Jean 1994; López-Acosta et al. 2018), and a previous study firstly estimated

72 that the sponge silica production represents ca. $8 \%$ of the net annual silica production in the Bay

73 (López-Acosta et al. 2018). Nevertheless, the large amounts of Si within the sponge bodies (i.e., the

74 Si standing stock) remain unquantified, as well as the fate of such Si once the sponges die. Herein,

75 we are estimating these parameters and providing the most complete cycle of Si through sponges for

76 this coastal ecosystem. The findings are discussed within the regional Si budget of the Bay of Brest

77 previously published by Ragueneau et al. (2005), which considered only the contribution of

78 planktonic diatoms.

$80 \quad$ Materials

81 Study area 
82 The Bay of Brest (NW France) is a semi-enclosed marine ecosystem of about $130 \mathrm{~km}^{2}$ (harbors

83 and estuaries not included) that is connected to the Atlantic Ocean through a narrow (1.8 km wide)

84 and deep (45 m) strait. The Bay is a shallow system, with a maximum depth of $40 \mathrm{~m}$ and a mean

85 depth of $8 \mathrm{~m}$. It is a macro-tidal (maximum tidal amplitude $=8 \mathrm{~m}$ ) system that receives high nutrient

86 loadings mainly from two small rivers (Fig. 1a). During all the year cycle, the tidal and wind currents

87 together with the shallowness of the Bay make nutrient concentration to remain relatively

88 homogeneous in the water column (Delmas and Tréguer 1985; Salomon and Breton 1991; Le Pape et

89 al. 1996). 
bioRxiv preprint doi: https://doi.org/10.1101/2021.10.20.465147; this version posted October 21, 2021. The copyright holder for this preprint (which was not certified by peer review) is the author/funder, who has granted bioRxiv a license to display the preprint in perpetuity. It is made available under aCC-BY-NC-ND 4.0 International license.

(a)
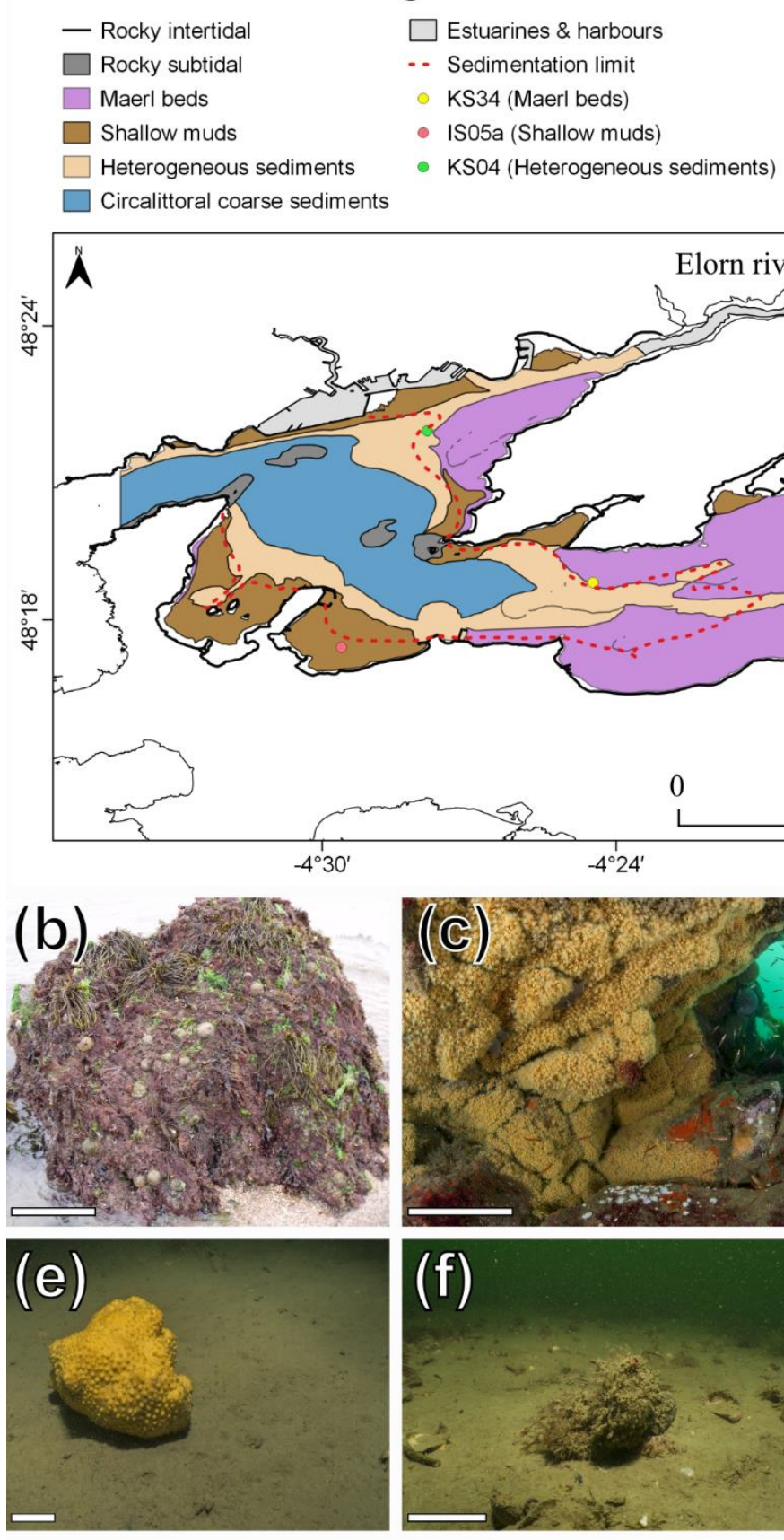

\section{Legend}

IS05a (Shallow muds)

- KS04 (Heterogeneous sediments)
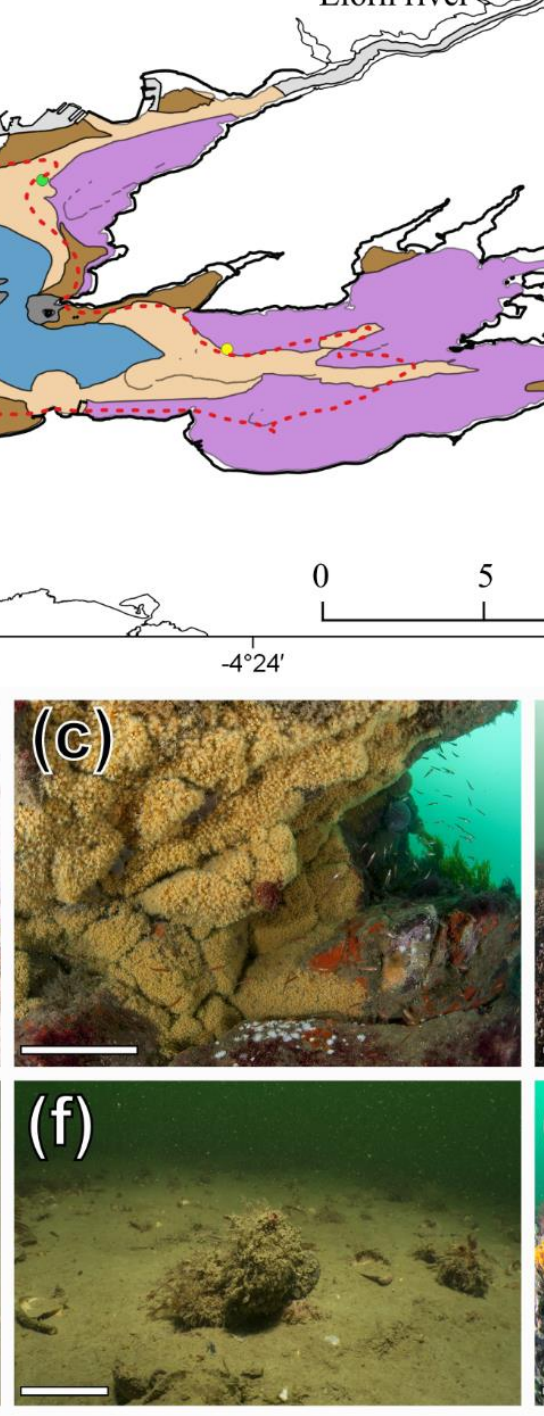

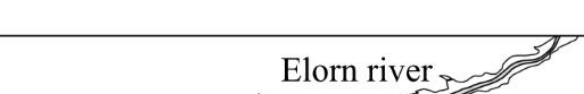

Elorn river
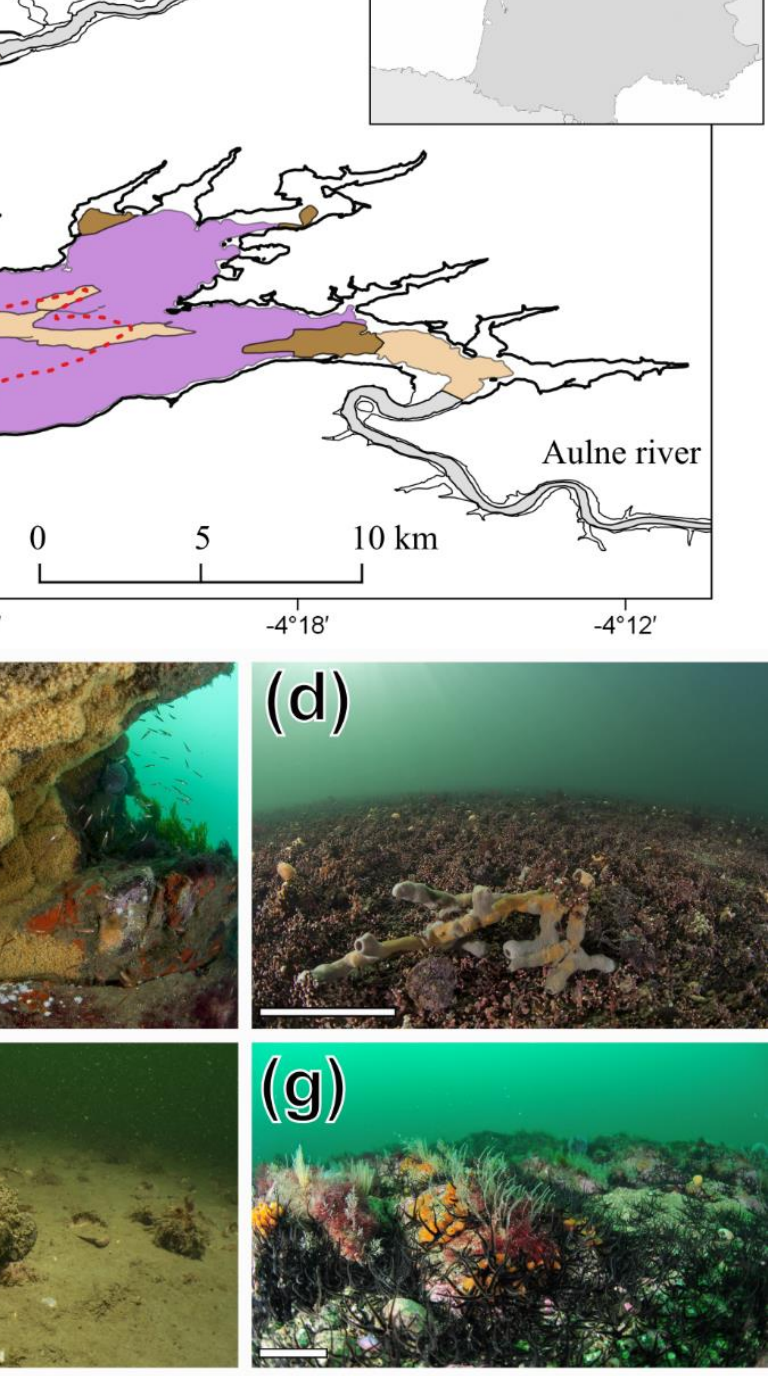

91 Fig. 1. (a) Map of the Bay of Brest (France), showing the six major habitats defined for this study

92 according to their depth, substrate type, and sponge fauna. Estuaries and harbors, depicted in grey in

93 the map, have not been considered in the study. Red dashed line indicates the limit of sedimentation

94 in the Bay, under which the sedimentation rate is negligible. Circles indicate the geographical 
location of the examined cores. (b-g) General view of the habitats of the Bay: (b) rocky intertidal, (c)

rocky subtidal, (d) maerl beds, (e) shallow muds, (f) heterogeneous sediments, and (g) circalittoral

coarse sediments. Scale bars indicate $10 \mathrm{~cm}$.

The Bay hosts abundant and diverse benthic communities, developed in a mixture of hard and soft

111 habitats of the Bay of Brest, which includes the up-to-date information of the bottom communities of

112 the Bay from the annual monitoring conducted by the Marine Observatory of the European Institute

113 for Marine Studies (Derrien-Courtel et al. 2019).

115 Table 1. Features of the benthic habitats of the Bay of Brest (France), including bottom area $116\left(10^{6} \mathbf{m}^{2}\right)$, relative contribution $(\%)$, sampled area $\left(\mathbf{m}^{2}\right)$, mean $( \pm \mathrm{SD})$ depth $(\mathbf{m})$, and richness of 
117 siliceous species of each habitat and the total Bay. RI, rocky intertidal; RS, rocky subtidal; MB,

118 maerl beds; SM, shallow muds; HS, heterogeneous sediments; CS, circalittoral coarse sediments.

\begin{tabular}{|c|c|c|c|c|}
\hline Habitat & $\begin{array}{c}\text { Bottom area } \\
\left(10^{6} \mathrm{~m}^{2}\right)\end{array}$ & $\begin{array}{c}\text { Sampled area } \\
\left(\mathrm{m}^{2}\right)\end{array}$ & $\begin{array}{c}\text { Depth } \\
\text { (m) }\end{array}$ & $\begin{array}{l}\text { Si species } \\
\text { richness }\end{array}$ \\
\hline RI & $1.98(1.5 \%)$ & 23 & $0.0( \pm 0.0)$ & 4 \\
\hline RS & $2.64(2.0 \%)$ & 31 & $12.4( \pm 4.0)$ & 31 \\
\hline MB & $45.84(34.4 \%)$ & 40 & $5.4( \pm 1.6)$ & 19 \\
\hline SM & $22.19(16.7 \%)$ & 17 & $5.1( \pm 3.0)$ & 2 \\
\hline HS & $31.79(23.9 \%)$ & 36 & $11.4( \pm 3.7)$ & 16 \\
\hline CS & $28.69(21.6 \%)$ & 23 & $25.6( \pm 4.5)$ & 32 \\
\hline Total & $133.13(100 \%)$ & 170 & $9.9( \pm 8.1)$ & 45 \\
\hline
\end{tabular}

\section{Silicon standing stock in sponge communities}

122 To estimate the Si standing stock of the sponge communities within the Bay of Brest, quantitative

123 surveys were conducted across the six benthic habitats. The sampling effort carried out within a

124 given habitat depended on both its relative surface to the total Bay extension and the relative internal

125 variation (Eberhardt 1978). Three sampling techniques were used for the different habitats: (1) the

126 rocky intertidal was sampled by using 23 random quadrats $(1 \times 1 \mathrm{~m})$ at low tides; (2) the rocky

127 subtidal, the maerl beds, the shallow mud, and the heterogeneous sediments above $20 \mathrm{~m}$ depth were

128 sampled by scuba diving using 119 random $1 \times 1 \mathrm{~m}$ quadrats; (3) the heterogeneous sediment and

129 circalittoral coarse sediment located below $20 \mathrm{~m}$ depth were sampled using an epibenthic trawl over

130 small transects $(1 \mathrm{~m}$ wide $\times 5-10 \mathrm{~m}$ long, trawl length precision $= \pm 1 \mathrm{~m} ; \mathrm{n}=28)$. Each sponge found

131 within the quadrats or in the trawls was counted, taxonomically identified to the species level, and

132 measured for volume and silica content (i.e., biogenic silica, bSi). To determine the sponge volume,

133 the body shape of each individual was approximated to one or a sum of several geometric figures

134 (e.g., sphere, cylinder, cone, rectangular plate, etc.) and the linear parameters needed to calculate the 135 volume (length, width, and/or diameter) were measured in situ using rulers (Maldonado et al. 2010). 
136 Counts and volume values in each habitat were normalized to $\mathrm{m}^{2}$. Non-siliceous sponge species were

137 taxonomically identified but not considered in the calculations.

138 The relationship between the mean siliceous sponge abundance (i.e., number of individuals) and

139 biomass (i.e., volume) in each habitat was normalized per $\mathrm{m}^{2}$ and analyzed by Spearman rank

140 correlation. Between-habitat differences in the sponge abundance and biomass per $\mathrm{m}^{2}$ were examined

141 by Kruskal-Wallis analysis when data did not meet normality and/or equal variance, following

142 Shapiro-Wilk and Brown-Forsythe tests, respectively. Post-hoc pairwise multiple comparisons

143 between groups were conducted using the non-parametric Dunn's test.

144 To estimate sponge silica content in a given sponge volume, a plastic cylinder of known volume

145 was filled with sponge tissue ( $\mathrm{n}=3$ to 5 for each species, depending on availability), applying

146 minimum compression. Sponge tissue samples were then dried at $60^{\circ} \mathrm{C}$ to constant dry weight $(\mathrm{g})$,

147 and desilicified by immersion in 5\% hydrofluoric acid solution for 5 hours, rinsed in distilled water

148 three times for 5 minutes, and dried again at $60^{\circ} \mathrm{C}$ to constant dry weight (Maldonado et al. 2010).

149 Silica content per unit of sponge volume $\left(\mathrm{mg} \mathrm{bSi} \mathrm{mL}^{-1}\right.$ sponge) was calculated as the difference in

150 weight before and after desilicification and multiplied by a factor of 0.8 . Such a factor was applied to

151 remove overestimates of the skeletal biogenic silica due to tiny sand grains (lithogenic silica) that

152 might be embedded into the sponge tissues (Maldonado et al. 2010).

153 Mean skeletal content ( $\mathrm{mg} \mathrm{bSi} \mathrm{mL}^{-1}$ sponge) of each species was subsequently used to estimate Si

154 standing stock in the sponge communities per unit of bottom area in the six habitats of the Bay, and

155 that at the ecosystem level. Between-habitat differences in mean sponge Si standing stock per $\mathrm{m}^{2}$

156 were examined by a Kruskal-Wallis analysis, followed by pairwise Dunn's tests to identify

157 significant differences between groups. Finally, the relationship between skeletal content and sponge

158 abundance per $\mathrm{m}^{2}$ and that between skeletal content and sponge biomass per $\mathrm{m}^{2}$ in the sponge

159 communities of the Bay were also examined using regression analysis. 


\section{Dissolved silicon consumption by sponge communities}

162 The annual consumption of $\mathrm{dSi}$ (and consequently biogenic silica production) by the sponge

163 communities of the Bay was estimated by using the dSi consumption kinetic models developed

164 elsewhere (López-Acosta et al. 2016, 2018) for the four dominant sponge species at the Bay

165 (Haliclona simulans, Hymeniacidon perlevis, Tethya citrina, and Suberites ficus). By knowing the

166 monthly average dSi availability in the bottom waters of the Bay over the last decade (2012-2021;

167 Table S1) and the consumption kinetics of each of the four dominant species at the Bay, the average

$168( \pm \mathrm{SD})$ annual dSi consumption rate by these species was estimated. This average was then

169 extrapolated to the rest of the sponge species in the Bay to estimate dSi consumption by habitat and

170 for the entire Bay, according to the previously estimated species sponge biomass per habitat (mL

171 sponge $\left.\mathrm{m}^{-2}\right)$ and habitat bottom area $\left(\mathrm{m}^{2}\right)$.

\section{Sponge biogenic silica in superficial sediments}

174 The amount of sponge $\mathrm{Si}$ in the sediments was determined by analyzing superficial sediments

175 samples (defined herein as the upper-centimeter layer of sediment) from three stations from the

176 shallow plateaus of the Bay of Brest (Fig. 1a). In the Bay, there are two major depositional

177 environments with contrasting features: 1) the shallow terraces or plateaus, up to $10 \mathrm{~m}$ depth, where

178 the fine sediment that regularly arrives through the rivers' discharges is homogeneously deposited,

179 and 2) the deepest bottoms, up to $40 \mathrm{~m}$ depth, where the strong tidal currents prevent the fine

180 sediment from being deposited on the bottom (Salomon and Breton 1991; Gregoire et al. 2017;

181 Lambert et al. 2017). The latter are located mainly in the central zone of the Bay and the two paleo-

182 channels that cross each of the basins of the Bay from the rivers' mouths to the central zone, where 
183 they converge (see Figure 1 in Gregoire et al. 2017). This depositional configuration was originated

184 by the action of successive sea-level low stands and it has been preserved over the last millennia by

185 the effect of tidal currents in deep-water areas, which keep the inherited shape by preventing the

186 deposition of the fine sediment supplied by rivers (Gregoire et al. 2016, 2017). As a consequence of

187 this hydrodynamic regime, the fine sediment does not settle on the deepest areas of the Bay, the

188 sediments of which mainly consist of coarse particles such as gross fragments of shells and small

189 pebbles (Gregoire et al. 2016). On the contrary, the fine sediment settles all over the shallow

190 plateaus, which are less affected by the tidal currents. Hence, the shallow plateaus account for

191 virtually the total area of sediment deposition in the Bay bottoms (Ehrhold et al. 2016). These

192 shallow plateaus, which account for about half of the Bay surface, are mainly covered by maerl beds,

193 shallow muds and partially by heterogeneous sediments (Fig. 1a; Table 2).

194 To estimate the amount of sponge silica in the superficial sediments of the Bay, one core was

195 sampled at each benthic habitat represented at the shallow plateaus: core SRQ3-KS34 from maerl

196 beds, core SRQ1-IS05 from shallow muds, and core SRQ3-KS04 from heterogeneous sediments

197 (Fig. 1a, Table 2). Present-day sedimentation rates were estimated from radiocarbon dating of

198 superficial sediment in the cores (Gregoire et al. 2017; Ehrhold et al. 2021). The bottoms of the

199 deepest areas of the Bay, on which sedimentation rates are negligible (Ehrhold et al. 2016), were

200 interpreted as null contributors to the sponge silica accumulation in the Bay (see below).

Table 2. Summary of core features including core label, coordinates, depth $(\mathrm{m})$, average $( \pm \mathrm{SD})$

204 of the benthic habitat over the sedimentation limit of the Bay $\left(\mathbf{k m}^{\mathbf{2}}\right)$. Present-day sedimentation 
rates for the superficial sediments of each core were estimated from ${ }^{14} \mathrm{C}$ radiocarbon dating in

206 Gregoire et al. (2017) and Ehrhold et al. (2021).

\begin{tabular}{|c|c|c|c|c|c|c|}
\hline \multicolumn{4}{|c|}{ Coordinates } & \multirow{2}{*}{$\begin{array}{l}\text { Sedimentation rate } \\
\left(\mathrm{cm} \mathrm{y}^{-1}\right)\end{array}$} & \multirow{2}{*}{$\begin{array}{l}\text { Benthic habitat } \\
\text { compartment }\end{array}$} & \multirow{2}{*}{$\begin{array}{c}\text { Compartment } \\
\text { extension }\left(\mathrm{km}^{-2}\right)\end{array}$} \\
\hline Core label & Latitude & Longitude & Depth $(\mathrm{m})$ & & & \\
\hline SRQ3-KS34 & $48^{\circ} 18.760^{\prime} \mathrm{N}$ & $\overline{4^{\circ} 24.474^{\prime} \mathrm{W}}$ & 10 & $0.037( \pm 0.003)$ & Maerl beds (MB) & 40.06 \\
\hline SRQ1-IS05a & $48^{\circ} 17.441^{\prime} \mathrm{N}$ & $4^{\circ} 29.609^{\prime} \mathrm{W}$ & 7 & $0.090( \pm 0.002)$ & Shallow muds (SM) & 17.21 \\
\hline SRQ3-KS04 & $48^{\circ} 21.858^{\prime} \mathrm{N}$ & $4^{\circ} 27.857^{\prime} \mathrm{W}$ & 7 & $0.077( \pm 0.001)$ & $\begin{array}{l}\text { Heterogeneous } \\
\text { sediments (HS) }\end{array}$ & 9.18 \\
\hline
\end{tabular}

To quantify the sponge silica in the superficial sediment layer, one to three sediment subsamples

211 light microscopy, following the methodology described in Maldonado et al. (2019). Briefly, sediment

212 subsamples were transferred to test tubes, boiled in $37 \%$ hydrochloric acid to remove calcareous

213 materials, then in $69 \%$ nitric acid to complete digestion of organic matter, rinsed in distilled water,

214 and sonicated for 15 minutes to minimize sediment aggregates. The sediment suspension was then

215 pipetted out and dropped on a microscope glass slide to measure the volume of each skeletal piece. A

216 total of 230 smear slides in which 48320 spicules, either entire or fragmented, were examined

217 through contrast-phase compound microscopes. Using digital cameras and morphometric software

218 (ToupView, ToupTek Photonics), the volume of each spicule or spicule's fragment was estimated by

219 approximating its shape to one or the sum of several geometric figures (Maldonado et al. 2019).

220 Measured volumes of sponge silica were subsequently converted into Si mass, using the average

221 density of $2.12 \mathrm{~g} \mathrm{~mL}^{-1}$ for sponge silica (Sandford 2003).

222 To determine the reservoir of sponge silica in the superficial sediment of the Bay, the obtained

223 mass of sponge silica per gram of sediment in each core was extrapolated to the area of each benthic

224 habitat over the sedimentation limit, delimited with a red dashed line in Figure 1 from the 
sedimentological data published in Ehrhold et al. (2016). It means that the sponge silica mass per gram of sediment from core SRQ3-KS34 was extrapolated to $40.06 \mathrm{~km}^{2}$, that of core SRQ1-IS05 to

$17.21 \mathrm{~km}^{2}$, and that of core SRQ3-KS04 to $9.18 \mathrm{~km}^{2}$ (Table 2). Sponge Si deposition rate was

superficial sediments and the average percentage estimated for sponge Si preservation in sediments between the sponge Si deposition and burial rates.

\section{Sponge silica budget in a coastal ecosystem: the Bay of Brest}

The quantified stocks and fluxes of sponge Si were used to build a sponge Si budget for the Bay of

\section{General features of the sponge assemblages}

243 The survey of the sponge fauna at the Bay of Brest revealed a total of 53 sponge species, most of

244 them belonging to the class Demospongiae $(n=51)$, and only 2 species belonging to the class Calcarea

245 (Table S2). Species from classes Hexactinellida and Homoscleromorpha were not found. Forty-five

$246(85 \%)$ of the 53 identified species had siliceous skeletons. The other 8 were non-siliceous sponge 
species with a skeleton made of either calcium carbonate $(n=2)$ or skeletal protein $(n=6)$. Non-

siliceous sponges were not considered in the following quantifications of sponge abundance and

biomass.

Sampling yielded a total of 1807 sponge individuals for which volume was determined (Table 1).

At the Bay level, the siliceous sponge fauna averaged $11.0 \pm 11.1$ individuals $\mathrm{m}^{-2}$ and a biomass of

to the sponge abundance and biomass normalized per $\mathrm{m}^{2}$ is derived from the patchy spatial

distribution of the sponges at both intra- and inter-habitat level. In contrast, the standard error (SE) of

the mean $(=\mathrm{SD} / \sqrt{ } \mathrm{N})$ is low $(\mathrm{SE}$ of sponge abundance $=0.85 ; \mathrm{SE}$ of sponge biomass $=0.03$ ),

indicating that mean values are accurate. A Spearman's correlation involving the six habitats

revealed a strong positive linear relationship between the mean abundance and biomass of siliceous

sponges per $\mathrm{m}^{2}$ of sampled bottom $(\mathrm{N}=6, \rho=0.886, p=0.033)$. This relationship informs that body

size is more or less uniformly distributed across species and specimens of the different habitats.

At the habitat level, there were large between-habitat differences in both sponge abundance and

biomass (Fig. 2). The total number of siliceous sponges per $\mathrm{m}^{2}$ significantly differs between habitats

of the maerl beds and rocky subtidal habitats $\left(24.6 \pm 26.2\right.$ and $16.4 \pm 9.3$ individuals $\mathrm{m}^{-2}$,

sponges $\left(\mathrm{L} \mathrm{m}^{-2}\right)$ also differed significantly between habitats $(\mathrm{H}=78.324, \mathrm{df}=5, p<0.001)$. A

posteriori pairwise comparison revealed that mean sponge biomass per $\mathrm{m}^{2}$ at the rocky subtidal

habitat, which showed the highest sponge biomass per sampled bottom $\left(3.8 \pm 9.7 \mathrm{~L} \mathrm{~m}^{-2}\right)$, was 
271 heterogeneous sediments and rocky intertidal habitat. Mean sponge biomass per $\mathrm{m}^{2}$ at shallow muds

272 and circalittoral coarse sediments were similar to each other and significantly lower than those at the

273 rest of habitats in the Bay (Fig. 2b-c).
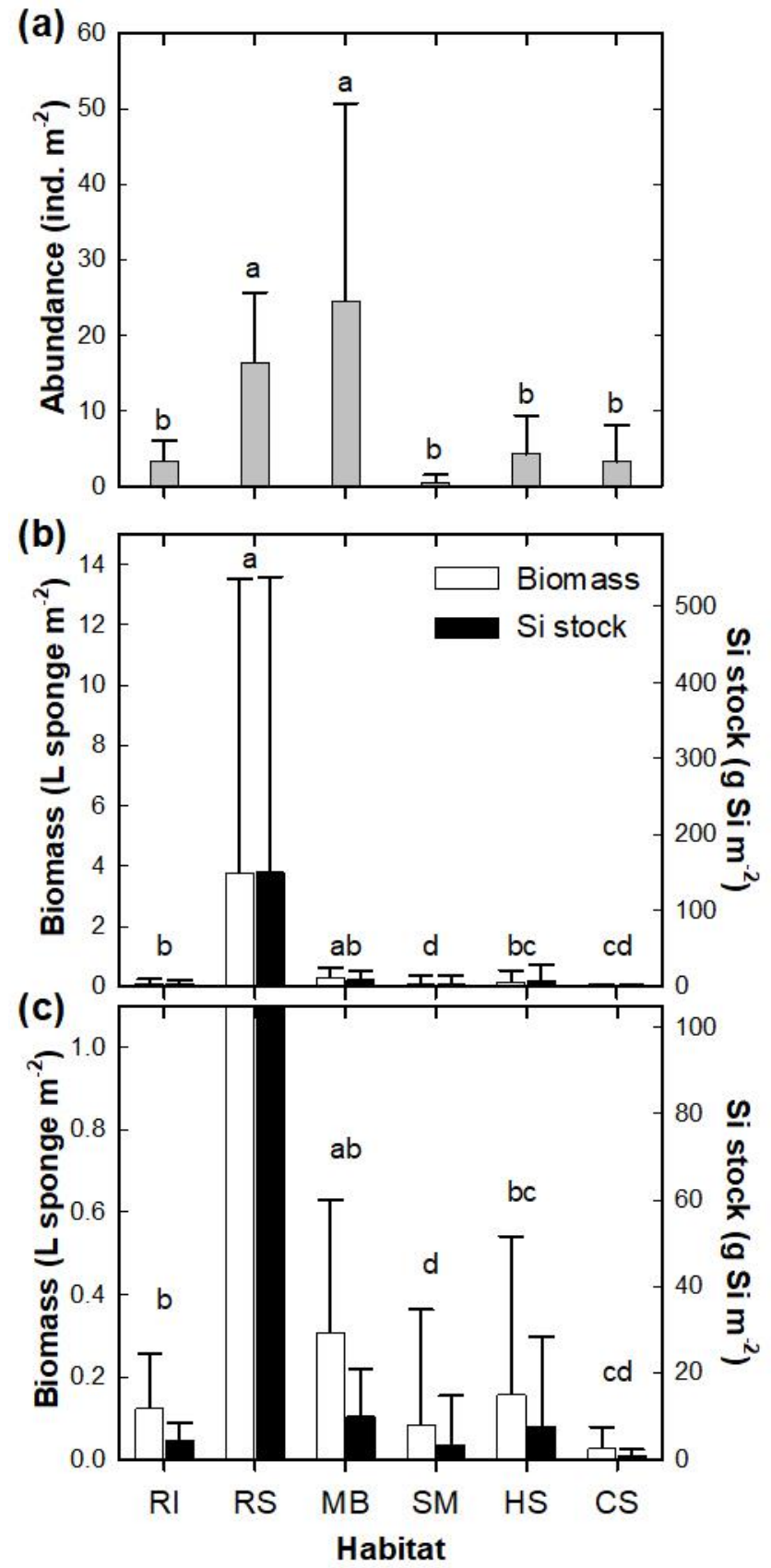
Fig. 2. Summary of (a) average ( \pm SD) abundance (individuals $\left.\mathrm{m}^{-2}\right)$, (b-c) biomass $\left(\mathrm{L}^{\text {sponge } \mathrm{m}^{-}}\right.$

2; white bars), and silicon (Si) standing stock (g Si mª $^{-2}$, black bars) in the siliceous sponge fauna

of the habitats of the Bay of Brest (France). Significant between-habitat differences of (a)

abundance and (b) biomass and Si stock of the sponge fauna are indicated with different letters

according to the results of Kruskal-Wallis analysis and the a posteriori pairwise Dunn's tests. (c) This graph makes visible the contribution of the habitats with sponge biomass and Si standing stock sediments, and CS for circalittoral coarse sediments.

\section{Silicon standing stock in the sponge communities}

The importance of the siliceous skeleton content per mass unit of sponge tissue varied largely

between sponge species (Table 3). It ranged from $29.8 \pm 2.9$ to $145.6 \pm 14.2 \mathrm{mg} \mathrm{bSi}$ per $\mathrm{mL}$ of living 
$10.7 \mathrm{~g} \mathrm{Si} \mathrm{m}^{-2}$ (Fig. 2b-c). In this habitat there is large abundance of sponges $(24.6 \pm 26.2$ individuals

$300 \mathrm{~m}^{-2}$ ) with body size ranging from small to medium (mean biomass $=12.4 \pm 37.1 \mathrm{~mL}^{\text {individual }^{-1}}$ ).

301 Four of the 19 siliceous sponge species identified at this habitat accounted for $84 \%$ of the total

302 sponge Si standing stock (Haliclona simulans, Hymeniacidon perlevis, Tethya citrina, and Suberites

303 ficus). A Kruskal-Wallis analysis confirmed that the between-habitat differences in sponge Si

304 standing stock per $\mathrm{m}^{2}$ are statistically significant $(\mathrm{H}=71.701, \mathrm{df}=5, p<0.001)$. The pairwise

305 comparison of mean Si standing stock revealed the same pattern of between-habitat differences than

306 that obtained in the pairwise comparison of mean sponge biomass (Fig. 2b-c). Further analysis

307 indicated a significant linear relationship $\left(\mathrm{n}=170, \mathrm{R}^{2}=0.999, p<0.0001\right)$ between sponge biomass

308 and Si standing stock per $\mathrm{m}^{2}$ across habitats (Fig. 3).

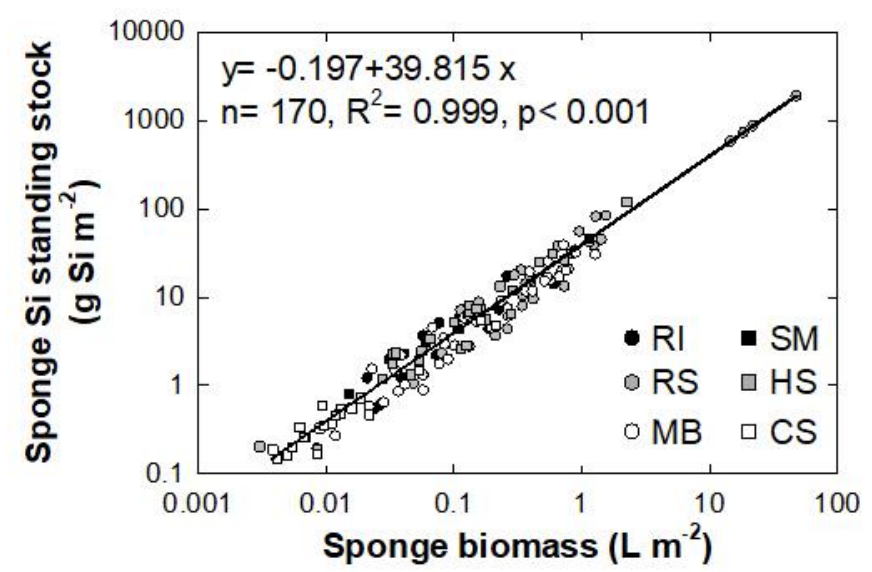

311 Fig. 3. Relationship between silicon (Si) standing stock $\left(\mathrm{g} \mathrm{Si} \mathrm{m}^{-2}\right)$ and biomass $\left(\mathrm{L} \mathrm{m}^{-2}\right) \mathrm{of}^{-}$

312 siliceous sponges per $\mathbf{m}^{\mathbf{2}}$ of sampled bottom at the Bay of Brest (France). Symbols represent the

313 location of the data (i.e., habitat; abbreviations mean: RI, rocky intertidal; RS, rocky subtidal; MB,

314 maerl beds; SM, shallow muds; HS, heterogeneous sediments; CS, circalittoral coarse sediments).

315 Sponge Si stock and biomass are shown in logarithmic scale. 
317 By integrating the average Si content of the sponges across the bottom area of each habitat, a total

318 Si standing stock of $1215 \pm 1876 \times 10^{3} \mathrm{~kg} \mathrm{Si}\left(43.3 \pm 66.8 \times 10^{6} \mathrm{~mol} \mathrm{Si}\right)$ in the sponge communities of

319 the Bay of Brest was estimated. The small-scale patchiness in the spatial distribution of the sponges

320 within a habitat causes some sampling quadrats to contain many sponges while others contain very

321 few or none. This effect, when propagated for the calculation of the global mean of the Bay, results in

322 a large SD value. In addition, about $90 \%$ of the stock is accumulated in the sponge fauna of three

323 habitats, which — in order of contribution — are the maerl beds, the rocky subtidal, and the

324 heterogeneous sediments.

326 Dissolved silicon consumption by sponge communities

327 The average monthly concentrations of dSi at the bottom waters of the Bay ranged from 2 to 13

$328 \mu \mathrm{M}$ (Table S1). At these nutrient concentrations, the most abundant species at the Bay (H. perlevis,

$32968.6 \pm 85.1 \mathrm{~mL} \mathrm{~m}^{-2}$ ) consumed $7.2 \pm 8.9 \mathrm{mmol} \mathrm{Si} \mathrm{m}^{-2} \mathrm{y}^{-1}$. Interestingly, the species $T$. citrina and $S$.

330 ficus, which show comparatively lower biomass records in the Bay $(24.5 \pm 34.1$ and $7.7 \pm 13.3 \mathrm{~mL}$

$331 \mathrm{~m}^{-2}$, respectively), had similar rates of Si consumption $\left(7.5 \pm 10.5\right.$ and $7.1 \pm 21.0 \mathrm{mmol} \mathrm{Si} \mathrm{m}^{-2} \mathrm{y}^{-1}$,

332 respectively). This is because their affinity for $\mathrm{dSi}$ is higher (affinity coefficient, $\mathrm{V}_{\max } / \mathrm{K}_{\mathrm{M}}=6.9 \times 10^{-3}$

333 and $4.4 \times 10^{-3} \mu \mathrm{mol} \mathrm{Si} \mathrm{h}{ }^{-1}$ sponge- $\mathrm{mL}^{-1} \mathrm{Si}_{-} \mu \mathrm{M}^{-1}$ for $T$. citrina and $\mathrm{S}$. ficus, respectively, compared to

$3342.1 \times 10^{-3} \mu \mathrm{mol} \mathrm{Si} \mathrm{h}{ }^{-1}$ sponge- $\mathrm{mL}^{-1} \mathrm{Si}-\mu \mathrm{M}^{-1}$ for $H$. perlevis).

335 Not surprisingly, most of the sponge Si consumption of the Bay occur in the rocky subtidal habitat

336 and maerl beds, where sponges are very abundant and they show moderate to large biomass records

337 (Fig. 2). The rocky subtidal habitat, which represents only $2.0 \%$ of the Bay bottom but hosts about

$33830 \%$ of the total sponge biomass in the Bay, shows an annual sponge Si consumption rate of $74.2 \pm$ 
$141.4 \times 10^{3} \mathrm{~kg} \mathrm{Si}^{-1}\left(2.6 \pm 5.0 \times 10^{6} \mathrm{~mol} \mathrm{Si}^{-1}\right)$. The maerl beds, in which H. perlevis, T. citrina, and

342 assemblage of siliceous sponges in the Bay is estimated to consume annually $200.8 \pm 372.1 \times 10^{3} \mathrm{~kg}$

$343 \quad \mathrm{Si} \mathrm{y}^{-1}\left(7.2 \pm 13.2 \times 10^{6} \mathrm{~mol} \mathrm{Si} \mathrm{y}^{-1}\right)$.

\section{Sponge bSi in sediments}

346 The superficial sediments (i.e., the upper 1-cm layer) of cores SRQ3-KS34, SRQ1-IS05a, and

347 SRQ3-KS04, contained respectively a total of $1.07( \pm 0.05), 1.30$, and 0.32 million spicules or spicule

348 fragments per $\mathrm{g}$ of sediment, with an average spicule content of $0.89( \pm 0.51)$ million spicules $\mathrm{g}^{-1}$

349 sediment for the set of studied cores (Table 4). In all cores, most spicules (98.3-99.1\%) were

350 recognized as megascleres, either entire or fragmented. The microscopic study of the superficial

351 sediment in the cores showed only small between-area differences in the mass of sponge bSi, which

352 ranged from 0.799 to $2.505 \mathrm{mg} \mathrm{Si} \mathrm{g}^{-1}$ sediment (Table 4). The average content of sponge bSi in the

353 sediments of the Bay of Brest was $1.565( \pm 0.866) \mathrm{mg} \mathrm{Si} \mathrm{g}^{-1}$ sediment.

355 Table 4. Summary of the results obtained during the microscopic examination of the superficial

356 sediments of the Bay of Brest. Average ( \pm SD, when available) spicule counts (in millions per gram

357 of sediment), contribution (\%) of megascleres (spicules longer than $100 \mu \mathrm{m}$ ) and microscleres

358 (spicules shorter than $100 \mu \mathrm{m}$ ), and mass of sponge silica per gram of sediment for each core are

359 indicated, as well as for the set of study cores. 


\begin{tabular}{|c|c|c|c|c|c|}
\hline \multirow[t]{2}{*}{ Core label } & \multirow[t]{2}{*}{ Benthic habitat } & \multirow{2}{*}{$\begin{array}{c}\mathrm{N} \text { spicules } \\
\left(\mathrm{N} \times 10^{6} \mathrm{~g}^{-1} \text { sed. }\right)\end{array}$} & \multicolumn{2}{|c|}{ Spicule-type contribution (\%) } & \multirow{2}{*}{$\begin{array}{c}\text { Sponge } \mathrm{Si} \text { in superficial sed. } \\
\left(\mathrm{mg} \mathrm{Si} \mathrm{g}^{-1} \text { sed.) }\right.\end{array}$} \\
\hline & & & Megascleres & Microscleres & \\
\hline $\begin{array}{l}\text { SRQ3-KS34 } \\
\text { SR }\end{array}$ & Maerl beds (MB) & $1.07( \pm 0.05)$ & $99.1( \pm 0.3)$ & $0.9( \pm 0.3)$ & $1.391( \pm 0.241)$ \\
\hline SRQ1-IS05a & Shallow muds (SM) & 1.30 & 99.0 & 1.0 & 2.505 \\
\hline SRQ3-KS04 & $\begin{array}{l}\text { Heterogeneous } \\
\text { sediments (HS) }\end{array}$ & 0.32 & 98.3 & 1.7 & 0.799 \\
\hline \multicolumn{2}{|c|}{$\overline{\text { AVERAGE }( \pm \text { SD })}$} & $0.89( \pm 0.51)$ & $98.8( \pm 0.4)$ & $1.2( \pm 0.4)$ & $1.565( \pm 0.866)$ \\
\hline
\end{tabular}

364 plateaus (i.e., $66.45 \mathrm{~km}^{2}$ ), it resulted in a mean deposition rate of $108.7 \pm 9.1 \times 10^{3} \mathrm{~kg} \mathrm{Si}^{-1}(3.9 \pm$

$\left.3650.3 \times 10^{6} \mathrm{~mol} \mathrm{Si} \mathrm{y}^{-1}\right)$. The sponge Si burial rate was then calculated from the deposition rate and the

366 average preservation rate of sponge silica determined by Maldonado et al. (2019) for continental-

367 shelf sediments. This approach yielded an average burial rate of sponge silica in the sediments of the

368 shallow plateaus of $57.3 \pm 18.2 \times 10^{3} \mathrm{~kg} \mathrm{Si}^{-1}\left(2.0 \pm 0.6 \times 10^{6} \mathrm{~mol} \mathrm{Si}^{-1}\right)$. The differences between

369 deposition and burial rate is, in the long run, the sponge contribution to the benthic Si efflux from

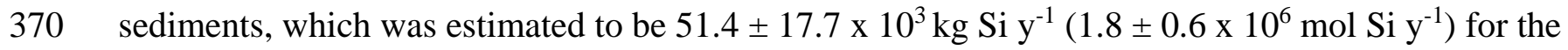

371 shallow plateaus of the Bay (Table 5).

$375\left(\mathrm{~km}^{2}\right)$ to which the sponge Si data were extrapolated is indicated. These areas do not correspond to

376 the total habitat extension but to the habitat area that is above the sedimentation limit of the Bay

377 (indicated with a red dashed line in Fig. 1a) for cores representing the shallow depositional plateaus. 


\begin{tabular}{|c|c|c|c|c|c|c|}
\hline \multirow[t]{2}{*}{ Core label } & \multirow[t]{2}{*}{ Benthic habitat } & \multirow{2}{*}{$\begin{array}{l}\text { Area } \\
\mathrm{km}^{2}\end{array}$} & \multirow{2}{*}{$\begin{array}{c}\text { Sponge Si STOCK } \\
\text { reservoir } \\
10^{3} \mathrm{~kg} \mathrm{Si} \\
\end{array}$} & \multicolumn{3}{|c|}{ Sponge Si FLUXES } \\
\hline & & & & $\begin{array}{c}\text { deposition rate } \\
10^{3} \mathrm{~kg} \mathrm{Si} \mathrm{y}^{-1}\end{array}$ & $\begin{array}{l}\text { burial rate } \\
10^{3} \mathrm{~kg} \mathrm{Si}^{-1}\end{array}$ & $\begin{array}{l}\text { benthic flux } \\
10^{3} \mathrm{~kg} \mathrm{Si}^{-1}\end{array}$ \\
\hline SRQ3-KS34 & Maerl beds (MB) & 40.06 & 937.93 & 34.91 & 18.39 & 16.52 \\
\hline SRQ1-IS05a & Shallow muds (SM) & 17.21 & 715.41 & 64.39 & 33.92 & 30.47 \\
\hline SRQ3-KS04 & $\begin{array}{l}\text { Heterogeneous } \\
\text { sediments (HS) }\end{array}$ & 9.18 & 121.70 & 9.38 & 4.94 & 4.44 \\
\hline TOTAL & & 66.45 & 1775.04 & 108.68 & 57.25 & 51.43 \\
\hline
\end{tabular}

\section{Discussion}

\section{Sponge fauna within the Bay of Brest}

393 the shallow muds and the rocky intertidal, showed low sponge species richness $(\leq 4$ species per habitat;

394 Table 1, Table S2). These two habitats, the former characterized by muddy bottoms and scanty hard 
substratum and the latter by periodic air exposures during low tides, hosted only a handful of species able to deal with those harsh conditions (Table S2).

The taxonomic composition and spatial distribution of the sponge fauna significantly differed

\section{Biogenic silica stock as sponge skeletons}

415 the sponge communities, the Si standing stock within the skeleton of the sponges totaled $1215 \pm 1876$

$416 \times 10^{3} \mathrm{~kg}$ of $\mathrm{Si}$. The siliceous skeleton accounted for 19.6-63.5\% of the sponge dry weight, depending 
418 bSi content and between-species variability was also reported in a sponge-rich community of the

419 Belizean Mesoamerican Barrier Reef (53.4 $\pm 6.1 \mathrm{mg} \mathrm{bSi} \mathrm{mL}{ }^{-1}$; Maldonado et al. 2010).

420 To date, only few studies have measured the amount of Si trapped in sponge communities of

421 shallow-water ecosystems. The sponge Si standing stock per $\mathrm{m}^{2}$ in the Bay of Brest $(12.3 \pm 14.1 \mathrm{~g} \mathrm{Si}$

$422 \mathrm{~m}^{-2}$ ) is about 5 times higher than that found in the sublittoral population of the encrusting

423 demosponge Crambe crambe at the Catalan coast of the NW Mediterranean $\left(2.5 \pm 2.7 \mathrm{~g} \mathrm{Si} \mathrm{m}^{-2}\right.$;

424 Maldonado et al. 2005) and, interestingly, similar to that measured in the sublittoral sponge-rich

425 assemblages of the Belize section of the Mesoamerican Barrier Reef (12.0 $\mathrm{g} \mathrm{Si} \mathrm{m}^{-2}$; Maldonado et al.

426 2010). The sponge Si standing stock of the Bay of Brest is also similar to that found at bathyal depths

427 at the westward slope of the Mauna Loa Volcano of Hawaii (12.6 $\mathrm{g} \mathrm{Si} \mathrm{m}^{-2}$; Maldonado et al. 2005),

428 where a dense monospecific population of the highly-silicified hexactinellid Sericolophus hawaiicus

429 occurs. Higher records of Si sponge stocks have only been reported from 1) the monospecific sponge

430 ground of the hexactinellid Vazella pourtalessii at the Nova Scotian continental shelf, Canada (43.8 \pm

$43174.6 \mathrm{~g} \mathrm{Si} \mathrm{m}^{-2}$; Maldonado et al. 2021), 2) the continental margins of Antarctica (178 $\mathrm{g} \mathrm{Si} \mathrm{m}^{-2}$; Gutt et

432 al. 2013), where heavily silicified demosponges and hexactinellids co-occur, and 3) the singular

433 epibathyal reefs of the hexactinellid Aphrocallistes vastus in British Columbia (Canada), where high

434 densities of heavily silicified individuals grow on exposed skeletons of dead sponges, leading to

435 outstanding accumulations of sponge silica in the form of siliceous reefs $\left(4238 \pm 924 \mathrm{~g} \mathrm{Si} \mathrm{m}^{-2}\right.$; Chu et

436 al. 2011). Altogether, these results support the idea that sponge communities are transient Si sinks

437 (Maldonado et al. 2005, 2010) and suggest that relevant standing stocks of sponge silica are likely to

438 occur not only in deep-sea and polar latitudes but also in shallow-water ecosystems from temperate

439 latitudes, in which diverse and abundant sponge populations may easily develop (Van Soest et al.

440 2012; Maldonado et al. 2017). 
441 The amount of sponge silica accumulated in only the superficial (upper centimeter) sediment layer

442 of the Bay of Brest $\left(1775 \pm 162 \times 10^{3} \mathrm{~kg} \mathrm{Si}\right.$; Fig. 4) falls in the same order of magnitude than that

443 accumulated in the living sponge fauna of the Bay $\left(1215 \pm 1876 \times 10^{3} \mathrm{~kg}\right.$; Fig. 4). The Si stock in the

444 superficial sediments is in the form of siliceous spicules that reach the sediments after sponge death

445 (Chou et al. 2012; Lukowiak et al. 2013; Maldonado et al. 2019), the abundance of which appears to

446 be proportional to the silica standing stock in the sponge communities living nearby (Bavestrello et

447 al. 1996; Lukowiak et al. 2013). The amounts of sponge silica deposited on the superficial sediments

448 of the Bay of Brest (0.799 - $2.505 \mathrm{mg} \mathrm{Si} \mathrm{g}^{-1}$ sediment; Table 4) are among the highest determined in

449 superficial sediments of continental margins from different oceans and seas $\left(0.014-2.572 \mathrm{mg} \mathrm{Si} \mathrm{g}^{-1}\right.$

450 sediment; Sañé et al. 2013; Maldonado et al. 2019). For instance, the amount of sponge silica

451 determined in the superficial sediments of the shallow muds (2.505 $\mathrm{mg} \mathrm{Si} \mathrm{g}^{-1}$ sediment, core SRQ1-

452 IS05a; Table 4) is nearly identical to that determined in the superficial sediments of the slope of the

453 Bransfield Strait in Antarctica (2.572 $\pm 0.861 \mathrm{mg} \mathrm{Si} \mathrm{g}^{-1}$ sediment; Maldonado et al. 2019), where

454 dense sponge aggregations occur (Ríos and Cristobo 2014; Kersken et al. 2016; Gutt et al. 2019).

455 Combining the cores examined in this study $\left(1.565 \pm 0.241 \mathrm{mg} \mathrm{Si} \mathrm{g}^{-1}\right.$ sediment$)$, the sediments of the

456 Bay had about $60 \%$ more sponge silica than the average estimated for the sediments of continental

457 margins in the global ocean $\left(0.924 \pm 0.854 \mathrm{mg} \mathrm{Si} \mathrm{g}^{-1}\right.$ sediment; Maldonado et al., 2019), indicating

458 that sediments from areas where sponges abound become an important reservoir of biogenic silica. 


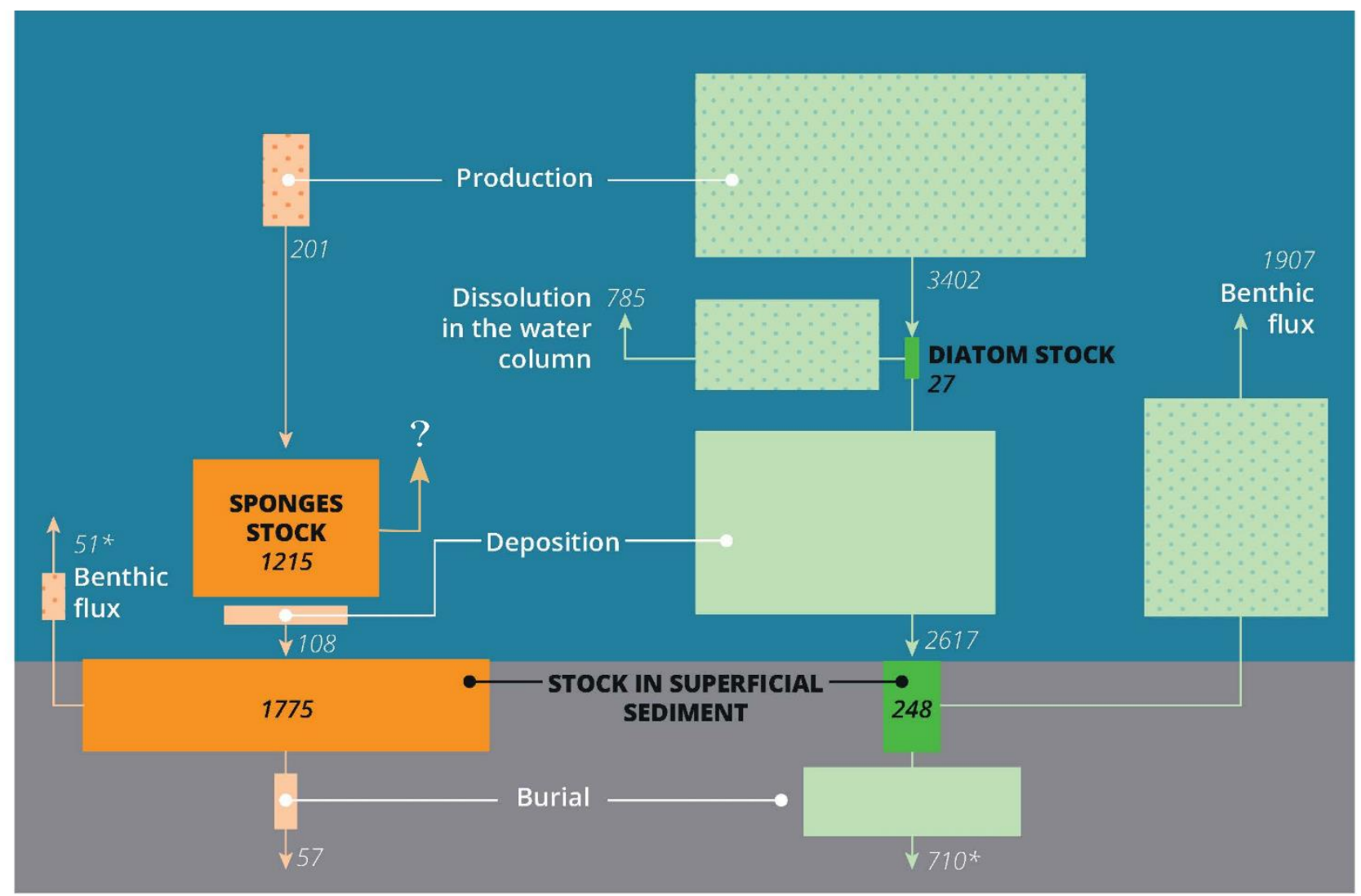

461 Fig. 4. Scheme summarizing the silicon stocks and fluxes through the sponge and planktonic

462 diatom communities of the Bay of Brest (France). Stocks and fluxes of silicon ( $\mathrm{Si}$ ) mediated by

463 sponges are in orange, and those mediated by diatoms are in green. Stocks of biogenic silica are

464 indicated in tons of Si. Fluxes of silicic acid, with a dotted pattern, and those of biogenic silica,

465 lacking the dotted pattern, are indicated in tons of Si per year. The size of the boxes representing both

466 stocks and fluxes is proportional to their rate. Fluxes of Si through diatoms are from Ragueneau et al.

467 (2005), stock of biogenic silica in planktonic diatoms has been calculated from Beucher et al. (2004),

468 and reservoir of diatom silica in superficial sediments are from Song and Ragueneau (2007); more

469 details about calculations in the main text. Asterisks $(*)$ refer to fluxes derived indirectly. 


\section{Silicon cycling through the sponge assemblage}

472

473

474

475

476

477

478

479

480

481

482

483

484

485

486

487

488

489

490

491

492

493

494

The siliceous skeletons produced by the sponges as part of their annual growth are progressively accumulated within the sponge body for the lifespan, which is thought to range from years to decades or centuries in shallow-water sponge species from temperate latitudes (McMurray et al. 2008;

Teixidó et al. 2011; McGrath et al. 2018). When a sponge dies or part of its body is removed or damaged by either natural or anthropogenic processes, the siliceous spicules within the sponge tissue are freed and end deposited on the superficial sediments (Chou et al. 2012; Lukowiak et al. 2013; Maldonado et al. 2019). In the Bay of Brest, the deposition of sponge silica was estimated to be 108 $\pm 9 \times 10^{3} \mathrm{~kg} \mathrm{Si}^{-1}$ (Fig. 4). Such rate is about twice smaller than the rate at which sponges produce silica in the Bay $\left(201 \pm 372 \times 10^{3} \mathrm{~kg} \mathrm{Si}^{-1}\right.$; Fig. 4). That would mean that the sponge fauna of the Bay of Brest would be increasing at a rate of $92 \pm 241 \times 10^{3} \mathrm{~kg} \mathrm{Si}^{-1}\left(3.3 \pm 8.6 \times 10^{6} \mathrm{~mol} \mathrm{Si}^{-1}\right)$, which would double the sponge Si standing stock (i.e., the sponge population) in about 13 years. In contrast, the sponge fauna survey of the Bay over the last 6 years and the long-term survey conducted in the area by the Marine Observatory of the IUEM since 1997 do not indicate that the sponge populations of the Bay are increasing at such high rate, rather the abundance and biomass of the sponge assemblages appear to be relatively constant in the long run (J. Grall, pers. comm.). Other reasons may also contribute to the imbalance between the annual silica production and deposition rates. First, the sponge mortality rate is unlikely to be constant every year. Indeed, a longer time frame (of at least a decade) is likely needed to capture the Si cycling dynamics in the sponge populations (McMurray et al. 2015; Bell et al. 2017). Second, there might be some partial rapid $(<1 \mathrm{y})$ dissolution of the spicules upon sponge death. Although sponge silica is more resistant to dissolution than that of others silicifiers (Rützler and Macintyre 1978; Erez et al. 1982; Maldonado et al. 2005, 2019), the most labile fraction of the sponge silica might be dissolved before the spicules being accumulated in the sediments. This would be in agreement with a recent study (Ng et al. 2020) that 
495 has measured through $\delta^{30} \mathrm{Si}$ that the remineralization of silica from demosponges — the same Class

496 of sponges as those occurring in the Bay of Brest - may be locally significant in superficial

497 sediments where sponges abound. In the study, $\mathrm{Ng}$ and co-authors determined that the benthic Si

498 effluxes from bottoms with sponges were from 2 to 10 times higher than those from sediments

499 without sponges. Finally, it cannot be excluded that part of the sponge silica deposited on the Bay

500 bottoms is exported out of the Bay during the monthly strong tidal currents during spring tides or

501 during extreme storms events, the force of which has been suggested to partially transport the

502 deposited sediments of the Bay (Beudin 2014). Further research is necessary to resolve which of

503 these processes, or if a combination of them, could explain the imbalance between the annual sponge

504 silica production and deposition rates at the Bay.

505 Through deposition, the sponge silica accumulates in the sediments of the Bay and is finally

506 buried at an average rate of $0.06 \mathrm{~cm} \mathrm{y}^{-1}$ (Gregoire et al. 2017; Ehrhold et al. 2021). Within the first

507 centimeters of marine sediments, biogenic silica — no matter its origin — dissolves progressively

508 until the interstitial water becomes saturated in $\mathrm{dSi}$, an asymptotic condition in which biogenic silica

509 dissolution typically ceases (Rickert et al. 2002; Sarmiento and Gruber 2006; Khalil et al. 2007). In

510 the sediments of the Bay of Brest, the interstitial water reaches dSi asymptote at $10-15 \mathrm{~cm}$ burial

511 depth (Raimonet et al. 2013), meaning that below that threshold, the amount of sponge silica buried

512 annually $\left(57 \pm 18 \times 10^{3} \mathrm{~kg} \mathrm{Si}^{-1}\right.$; Fig. 4) is preserved definitively in the sediments of the Bay. The

513 difference between the sponge silica deposited on superficial sediments and that buried definitively in

514 the sediments $\left(51 \pm 18 \times 10^{3} \mathrm{~kg} \mathrm{Si}^{-1}\right.$; Fig. 4) is assumed to be dissolved as interstitial dSi during the

515 early steps of burial. Such amount of dSi contributes to the saturation of interstitial water and

516 ultimately feeds the dSi benthic efflux from the sediments of the Bay toward the water column, a

517 recycling process that helps to sustain the populations of planktonic diatoms during the productive

518 season in the Bay (Chauvaud et al. 2000; Ragueneau et al. 2002). Further investigation on the 
519 processes involved in the dissolution of sponge silica during the early steps of burial would help to

520 quantify more accurately at which level the sponge Si contributes to the benthic dSi efflux.

\section{Sponge vs. diatom Si cycle at the Bay of Brest}

The biogeochemical cycling of Si in the Bay of Brest through planktonic diatoms is well studied

524 (e.g., Delmas and Tréguer, 1983; Del Amo et al., 1997; Chauvaud et al., 2000; Beucher et al., 2004)

525 and summarized in Ragueneau et al. (2005). This budget was based on diatom Si flux rates and did

526 not consider the sponge Si flux rates, nor the biogenic silica stocks of sponges and diatoms in the

527 living communities and sediments.

528 To compare the contribution of diatoms and sponges to the Si budget of the Bay, the standing

529 stocks and Si reservoirs in the form of diatom silica were determined from the literature. According

530 to it, the standing stock of diatoms in the water column of the Bay ranges from 0.12 to $1.98 \mu \mathrm{mol} \mathrm{Si}$

$531 \mathrm{~L}^{-1}$ over the year cycle (Beucher et al. 2004). Unlike sponges, diatom cells have an ephemeral life of

532 only days. Therefore, the silica standing crop of planktonic diatoms is known to change drastically

533 from week to week and over seasons, depending on nutrient availability and hydrological conditions

534 (Sarthou et al. 2005; Falkowski and Oliver 2007; Armbrust 2009). If the annual mean of diatom silica

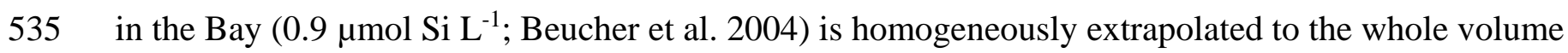

536 of the Bay of Brest $\left(1.07 \times 10^{12} \mathrm{~L}\right)$, an average diatom silica standing stock of $27 \times 10^{3} \mathrm{~kg} \mathrm{Si}(1.0 \times$

$53710^{6} \mathrm{~mol} \mathrm{Si}$ ) is obtained (Fig. 4). This figure integrates the seasonal variability occurring over the year

538 cycle in the Bay, which range from a minimal value of $18 \times 10^{3} \mathrm{~kg} \mathrm{Si}\left(0.6 \times 10^{6} \mathrm{~mol} \mathrm{Si}\right)$ in winter to a

539 maximum value of $36 \times 10^{3} \mathrm{~kg} \mathrm{Si}\left(1.3 \times 10^{6} \mathrm{~mol} \mathrm{Si}\right)$ in spring. 
540 The fate of diatom silica in superficial sediments is largely influenced by the active filter-feeding

541 of mollusks in the Bay, which defecate Si-rich feces that facilitate the retention of diatom silica at the

542 sediment surface (Chauvaud et al. 2000; Ragueneau et al. 2002, 2005). The content of diatom silica

543 in the superficial sediment of the Bay was determined from the analysis of 86 sediment samples from

54443 stations across the Bay, which capture both the intra-annual variability (43 samples were sampled

545 in winter and 43 in late summer) and the different depositional environments of the Bay (Song and

546 Ragueneau 2007). It resulted in an average diatom silica reservoir in the superficial sediments of the

547 Bay of $248 \times 10^{3} \mathrm{~kg} \mathrm{Si}\left(8.8 \times 10^{6} \mathrm{~mol} \mathrm{Si}\right.$; Fig. 4).

548 When the Si stocks and fluxes of sponges are compared with those of planktonic diatoms, there

549 are marked differences (Fig. 4). The rates at which Si is processed through diatoms are one order of

550 magnitude higher than those through sponges. On the contrary, diatom Si stocks are between 7 to 45

551 times smaller than those of sponges (Fig. 4), in agreement with the only study to date comparing Si

552 standing stocks in sponges and diatoms in a coastal ecosystem (Maldonado et al. 2010). These

553 differences indicate that sponges and diatoms play their respective roles in the Si budget of the Bay at

554 different speeds and through different mechanisms. The turnover of the diatom silica standing stock

555 (i.e., standing stock : production rate) in the Bay is about 3 days, whereas that of sponge silica is

556 about 6 years, that is, approximately 800 times slower than that of diatom silica. Similarly, the

557 turnover of diatom silica stock in superficial sediments (i.e., reservoir in sediment : deposition rate) is

558 about 1 month, whereas that of sponge silica is about 16 years (ca. 170 times that of diatom silica).

559 This means that the cycling of Si through diatoms is comparatively faster, with Si mainly cycling

560 through them (repeatedly over a year) rather than being accumulated. In contrast, Si accumulates in

561 huge amounts in sponges over long periods ( $\geq 10 \mathrm{y})$, being slowly processed through them. These

562 results show that impacts on either the sponge populations or the sediments nearby sponge 
563 aggregations could have a long-term impact on the sponge Si cycling dynamics, which will require

564 decades to be restored.

566 Conclusion

567 In shallow-water ecosystems, planktonic and benthic silicifiers have to share the dSi pool and 568 compete to incorporate this nutrient, which is critical for the growth of both organisms. Our study

569 highlights that even in coastal, shallow-water systems with a high primary productivity dominated by

570 planktonic diatoms — such as the Bay of Brest, sponges may account for a stock of biogenic silica as

571 large as $89-98 \%$. This stock cycles slowly compared to that of diatoms and accumulates bSi in the

572 sediments. These results suggest that the Si cycling through sponge communities is substantially

573 different from that through diatom assemblages. Therefore, the comparison between the roles of these

574 two groups of silicifiers is not straightforward due to their contrasting biological features (e.g.,

575 benthic and long living vs planktonic and short living). Yet these two types of silicifiers need to be 576 quantitatively integrated in future approaches, if we aim to understand in depth the intricacies of the

577 Si cycle in coastal systems.

\section{Acknowledgments}

580 The authors thank Erwan Amice, Isabelle Bihannic, and Thierry Le Bec for assistance during

581 underwater fieldwork and for pictures of Fig. 1b-g. Marta García Puig and Marcos Navas Durán are

582 thanked for helping with the data management of spicule counting. The authors also thank the staff

583 maintaining the Lanvéoc database for making public their information on nutrient availability at the 
bottom waters of the Bay of Brest and Sébastien Hervé for the artwork of Fig. 4. Jill Sutton and Fiz

585 Fernández are especially thanked for their comments on the manuscript. This research was supported

586 by two Spanish Ministry grants (CTM2015-67221-R and MICIU: \#PID2019-108627RB-I00) to MM,

587 the French National research program EC2CO (grant 12735 - AO2020) to JG, and the ISblue project,

588 Interdisciplinary graduate school for the blue planet (ANR-17-EURE-0015), co-funded by a grant

589 from the French government under the program "Investissements d'Avenir", to MLA. MLA thanks

590 the Xunta de Galicia for her postdoctoral grant (IN606B-2019/002), which also supported this work.

591 The authors declare no conflict of interest.

593 Author Contributions

594 MLA and MM conceived and designed the study. MLA conducted the sponge fieldwork, with the

595 help of JG and AL. MLA, MM, and CS taxonomically identified the sponges. MLA processed the

596 sponge samples to determine specific silica content. AH sampled the sediment cores and provided

597 sedimentary data. JG and AH provided the bottom mapping data and MLA developed the benthic

598 habitat and spicule accumulation layers. MLA, CG, and CS conducted sponge silica determination

599 under the microscope. MLA analyzed and interpreted the data and drafted the manuscript, with

600 invaluable inputs made by MM and AL. All authors contributed with comments to the manuscript

601 and approved the submitted version.

602

\section{References}


604 Armbrust, E. V. 2009. The life of diatoms in the world's oceans. Nature 459: 185-192.

605 doi:10.1038/nature08057

606 Ávila, E., and R. Riosmena-Rodriguez. 2011. A preliminary evaluation of shallow-water rhodolith beds in Bahia Magdalena, Mexico. Braz. J. Oceanogr. 59: 365-375. doi:10.1590/S167987592011000400007 spicules to the composition of biogenic silica in the Ligurian Sea. Mar. Ecol. 17: 41-50.

Bell, J. J., A. Biggerstaff, T. Bates, H. Bennett, J. Marlow, E. McGrath, and M. Shaffer. 2017. Sponge monitoring: moving beyond diversity and abundance measures. Ecol. Indic. 78: 470488. doi:10.1016/j.ecolind.2017.03.001

Beucher, C., P. Treguer, R. Corvaisier, A. M. Hapette, and M. Elskens. 2004. Production and dissolution of biosilica, and changing microphytoplankton dominance in the Bay of Brest (France). Mar. Ecol. Prog. Ser. 267: 57-69. doi:10.3354/meps267057

Beudin, A. 2014. Dynamique et échanges sédimentaires en rade de Brest impactés par l'invasion de crépidules. Ph.D. thesis. Université de Bretagne Occidentale.

620 Chauvaud, L., F. Jean, O. Ragueneau, and G. Thouzeau. 2000. Long-term variation of the Bay of Brest ecosystem: benthic-pelagic coupling revisited. Mar. Ecol. Prog. Ser. 200: 35-48.

623 Chou, Y., J. Y. Lou, C.-T. A. Chen, and L.-L. Liu. 2012. Spatial distribution of sponge spicules in sediments around Taiwan and the Sunda Shelf. J. Oceanogr. 68: 905-912. doi:10.1007/s10872-012-0143-7 
626 Chu, J. W. F., M. Maldonado, G. Yahel, and S. P. Leys. 2011. Glass sponge reefs as a silicon sink. Mar. Ecol. Prog. Ser. 441: 1-14. doi:10.3354/meps09381

628 Davidson, K., R. J. Gowen, P. J. Harrison, L. E. Fleming, P. Hoagland, and G. Moschonas. 2014. Anthropogenic nutrients and harmful algae in coastal waters. J. Environ. Manage. 146: 206216. doi:10.1016/j.jenvman.2014.07.002

631 Del Amo, Y., B. Quéguiner, P. Tréguer, H. Breton, and L. Lampert. 1997. Impacts of high-nitrate

Delmas, R., and P. Tréguer. 1983. Evolution saisonnière des nutriments dans un écosystème eutrophe de l'Europe Occidentale (la Rade de Brest). Interactions marines et terrestres. Oceanol. Acta year-round dominance of diatoms in the Bay of Brest (France). Mar. Ecol. Prog. Ser. 161:

Delmas, R., and P. Tréguer. 1985. Simulation de l'évolution de paramètres physiques, chimiques, et de la biomasse phytoplanctonlque en période printanière dans un écosystème littoral

DeMaster, D. J. 2003. The diagenesis of biogenic silica: chemical transformations occurring in the water column, seabed, and crust, p. 87-98. In F.T. Mackenzie [ed.], Treatise on

644 Derrien-Courtel, S., T. Androuin, E. Ar Gall, and others. 2019. Surveillance du Benthos du littoral Breton. Années 2017-2018 Rapport final. Museum d'Histoire Naturelle de Paris.

646 Eberhardt, L. L. 1978. Appraising variability in population studies. J. Wildlife Manage. 42: 207. 
648 Ehrhold, A., G. Gregoire, S. Sabine, G. Jouet, and P. Le Roy. 2016. Present-day sedimentation rates and evolution since the last maximum flooding surface event in the Bay of Brest (W-N

Ehrhold, A., G. Jouet, P. Le Roy, and others. 2021. Fossil maerl beds as coastal indicators of late Holocene palaeo-environmental evolution in the Bay of Brest (Western France). Palaeogeography, Palaeoclimatology, Palaeoecology 577: 110525. doi:10.1016/j.palaeo.2021.110525

Erez, J., K. Takahashi, and S. Honjo. 1982. In-situ dissolution experiment of radiolaria in the central North Pacific ocean. Earth Planet. Sci. Lett. 59: 245-254. doi:10.1016/0012-821X(82)90129-

Falkowski, P. G., and M. J. Oliver. 2007. Mix and match: how climate selects phytoplankton. Nat. Rev. Microbiol. 5: 813-819. doi:10.1038/nrmicro1751 Recent advances, new paradigms, and continuing challenges. Oceanography 30: 58-69.

662 Grall, J., and M. Glémarec. 1997. Biodiversity of maerl beds in Brittany: functional approach and 663 anthropogenic impacts. Vie et Milieu 47: 339-349.

664 Gregoire, G., A. Ehrhold, P. Le Roy, G. Jouet, and T. Garlan. 2016. Modern morphosedimentological patterns in a tide-dominated estuary system: the Bay of Brest (west Britanny, France). J. Maps 12: 1152-1159. doi:10.1080/17445647.2016.1139514

667 Gregoire, G., P. Le Roy, A. Ehrhold, G. Jouet, and T. Garlan. 2017. Control factors of Holocene 668 sedimentary infilling in a semi-closed tidal estuarine-like system: the bay of Brest (France). Mar. Geol. 385: 84-100. doi:10.1016/j.margeo.2016.11.005 
670 Gutt, J., J. Arndt, C. Kraan, B. Dorschel, M. Schröder, A. Bracher, and D. Piepenburg. 2019. Benthic communities and their drivers: a spatial analysis off the Antarctic Peninsula. Limnol.

Gutt, J., A. Bohmer, and W. Dimmler. 2013. Antarctic sponge spicule mats shape macrobenthic diversity and act as a silicon trap. Mar. Ecol. Prog. Ser. 480: 57-71. doi:10.3354/meps 10226

Hily, C., P. Potin, and J.-Y. Floch. 1992. Structure of subtidal algal assemblages on soft-bottom sediments: fauna/flora interactions and role of disturbances in the Bay of Brest, France. Mar. Guldberg [eds.], The Great Barrier Reef: biology, environment and management. benthique de la rade de Brest (France). Ph.D. thesis. Université de Bretagne Occidentale.

Kersken, D., B. Feldmeyer, and D. Janussen. 2016. Sponge communities of the Antarctic Peninsula: influence of environmental variables on species composition and richness. Polar Biol. 39: diagenetic models and experimental dissolution rates. Mar. Chem. 106: 223-238. doi:10.1016/j.marchem.2006.12.004

Kristiansen, S., and E. E. Hoell. 2002. The importance of silicon for marine production. Hydrobiologia 484: 21-31. doi:10.1023/A:1021392618824 

doi:10.1016/j.revpalbo.2017.04.005 Resistance of a coastal ecosystem to increasing eutrophic conditions: the Bay of Brest (France), a semi-enclosed zone of Western Europe. Cont. Shelf Res. 16: 1885-1907. doi:10.1016/0278-4343(95)00068-2 marine sponges: an assessment of their role at the ecosystem level. Limnol. Oceanogr. 63:

López-Acosta, M., A. Leynaert, and M. Maldonado. 2016. Silicon consumption in two shallow-water sponges with contrasting biological features. Limnol. Oceanogr. 61: 2139-2150. doi:10.1002/lno.10359

Lukowiak, M., A. Pisera, and A. O’Dea. 2013. Do spicules in sediments reflect the living sponge community? A test in a Caribbean shallow-water lagoon. PALAIOS 28: 373-385. doi:10.2110/palo.2012.p12-082r habitats: a synthetic review of types, structure, functional roles, and conservation concerns, $\mathrm{p}$. 
716

717

718

719

720

721

722

723

724

725

726

727

728

729

730

731

732

733

734

735

736

737

Maldonado, M., C. Carmona, Z. Velásquez, A. Puig, A. Cruzado, A. López, and C. M. Young. 2005. Siliceous sponges as a silicon sink: an overlooked aspect of benthopelagic coupling in the marine silicon cycle. Limnol. Oceanogr. 50: 799-809. doi:10.4319/1o.2005.50.3.0799

Maldonado, M., M. López-Acosta, L. Beazley, E. Kenchington, V. Koutsouveli, and A. Riesgo. 2020. Cooperation between passive and active silicon transporters clarifies the ecophysiology and evolution of biosilicification in sponges. Sci. Adv. 6: eaba9322. doi:10.1126/sciadv.aba9322

Maldonado, M., M. López-Acosta, C. Sitjà, M. García-Puig, C. Galobart, G. Ercilla, and A. Leynaert. 2019. Sponge skeletons as an important sink of silicon in the global oceans. Nat. Geosci. 12: 815-822. doi:10.1038/s41561-019-0430-7

Maldonado, M., L. Navarro, A. Grasa, A. González, and I. Vaquerizo. 2011. Silicon uptake by sponges: a twist to understanding nutrient cycling on continental margins. Sci Rep 1: 8 . doi: $10.1038 /$ srep00030

Maldonado, M., A. Riesgo, A. Bucci, and K. Rützler. 2010. Revisiting silicon budgets at a tropical continental shelf: silica standing stocks in sponges surpass those in diatoms. Limnol. Oceanogr. 55: 2001-2010. doi:10.4319/lo.2010.55.5.2001

Malviya, S., E. Scalco, S. Audic, and others. 2016. Insights into global diatom distribution and diversity in the world's ocean. Proc Natl Acad Sci USA 113: E1516-E1525. doi:10.1073/pnas.1509523113

McGrath, E. C., L. Woods, J. Jompa, A. Haris, and J. J. Bell. 2018. Growth and longevity in giant barrel sponges: redwoods of the reef or pines in the Indo-Pacific? Sci Rep 8: 15317. doi:10.1038/s41598-018-33294-1 
738

739

740

741

742

743

744

745

746

747

748

749

750

751

752

753

754

755

756

757

758

759

McMurray, S. E., J. E. Blum, and J. R. Pawlik. 2008. Redwood of the reef: growth and age of the giant barrel sponge Xestospongia muta in the Florida Keys. Mar. Biol. 155: 159-171. doi:10.1007/s00227-008-1014-Z

McMurray, S. E., C. M. Finelli, and J. R. Pawlik. 2015. Population dynamics of giant barrel sponges on Florida coral reefs. J. Exp. Mar. Biol. Ecol. 473: 73-80. doi:10.1016/j.jembe.2015.08.007

Neill, K. F., W. A. Nelson, R. D’Archino, D. Leduc, and T. J. Farr. 2015. Northern New Zealand rhodoliths: assessing faunal and floral diversity in physically contrasting beds. Mar Biodiv 45: 63-75. doi:10.1007/s12526-014-0229-0

Ng, H. C., L. Cassarino, R. A. Pickering, E. M. S. Woodward, S. J. Hammond, and K. R. Hendry. 2020. Sediment efflux of silicon on the Greenland margin and implications for the marine silicon cycle. Earth Planet. Sci. Lett. 529: 115877. doi:10.1016/j.epsl.2019.115877

QGIS Development Team. 2020. QGIS Geographic Information System, Open Source Geospatial Foundation Project.

Quéguiner, B., and P. Tréguer. 1984. Studies on the phytoplankton in the bay of Brest (western Europe). Seasonal variations in composition, biomass and production in relation to hydrological and chemical features (1981-1982). Bot. Mar. 27: 449-459. doi:10.1515/botm.1984.27.10.449

Ragueneau, O., L. Chauvaud, A. Leynaert, and others. 2002. Direct evidence of a biologically active coastal silicate pump: ecological implications. Limnol. Oceanogr. 47: 1849-1854. doi:10.4319/lo.2002.47.6.1849

Ragueneau, O., L. Chauvaud, B. Moriceau, A. Leynaert, G. Thouzeau, A. Donval, F. Le Loc'h, and F. Jean. 2005. Biodeposition by an invasive suspension feeder impacts the biogeochemical 

doi:10.1007/s10533-004-5677-3

762

763

764

765

766

767

768

769

770

771

772

773

774

775

776

777

778

779

780

781

782

Ragueneau, O., D. J. Conley, A. Leynaert, S. N. Longphuirt, and C. P. Slomp. 2006. Role of diatoms in silica cycling and coastal marine food webs, p. 163-195. In V. Ittekkot, D. Unger, C. Humborg, and N.T. An [eds.], The silicon cycle: human perturbations and impacts on aquatic systems. Island Press.

Ragueneau, O., M. Raimonet, C. Mazé, and others. 2018. The impossible sustainability of the Bay of Brest? Fifty years of ecosystem changes, interdisciplinary knowledge construction and key questions at the science-policy-community interface. Front. Mar. Sci. 5: 124. doi:10.3389/fmars.2018.00124

Raimonet, M., O. Ragueneau, F. Andrieux-Loyer, X. Philippon, R. Kerouel, M. Le Goff, and L. Mémery. 2013. Spatio-temporal variability in benthic silica cycling in two macrotidal estuaries: Causes and consequences for local to global studies. Estuar. Coast. Shelf Sci. 119: 31-43. doi:10.1016/j.ecss.2012.12.008

Reincke, T., and D. Barthel. 1997. Silica uptake kinetics of Halichondria panicea in Kiel Bight. Marine Biology 129: 591-593. doi:10.1007/s002270050200

Rickert, D., M. Schlüter, and K. Wallmann. 2002. Dissolution kinetics of biogenic silica from the water column to the sediments. Geochim. Cosmochim. Acta 66: 439-455. doi:10.1016/S0016-7037(01)00757-8

Ríos, P., and J. Cristobo. 2014. Antarctic Porifera database from the Spanish benthic expeditions. ZooKeys 401: 1-10. doi:10.3897/zookeys.401.5522

Rützler, K., and I. G. Macintyre. 1978. Siliceous sponge spicules in coral-reef sediments. Mar. Biol. 49: 147-159. doi:10.1007/bf00387114 
783

784

785

786

787

788

789

790

791

792

793

794

795

796

797

798

799

800

801

802

803

804

805

Salomon, J. C., and M. Breton. 1991. Numerical study of the dispersive capacity of the Bay of Brest, France, towards dissolved substances, p. 459-464. In Environmental hydraulics.

Sandford, F. 2003. Physical and chemical analysis of the siliceous skeletons in six sponges of two groups (Demospongiae and Hexactinellida). Microsc. Res. Tech. 62: 336-355. doi:10.1002/jemt.10400

Sañé, E., E. Isla, M. Á. Bárcena, and D. J. DeMaster. 2013. A shift in the biogenic silica of sediment in the Larsen B continental shelf, off the Eastern Antarctic Peninsula, resulting from climate change V. Magar [ed.]. PLoS ONE 8: e52632. doi:10.1371/journal.pone.0052632

Sarmiento, J., and N. Gruber. 2006. Ocean biogeochemical dynamics, Princeton University Press.

Sarthou, G., K. R. Timmermans, S. Blain, and P. Tréguer. 2005. Growth physiology and fate of diatoms in the ocean: a review. J. Sea Res. 53: 25-42. doi:10.1016/j.seares.2004.01.007

Sciberras, M., M. Rizzo, J. R. Mifsud, K. Camilleri, J. A. Borg, E. Lanfranco, and P. J. Schembri. 2009. Habitat structure and biological characteristics of a maerl bed off the northeastern coast of the Maltese Islands (central Mediterranean). Mar. Biodiv. 39: 251-264. doi:10.1007/s 12526-009-0017-4

Song, Y. P., and O. Ragueneau. 2007. Le dosage de bSiO2 dans le sédiment de la rade de Brest. Master thesis. Université de Bretagne Occidentale.

Teixidó, N., J. Garrabou, and J.-G. Harmelin. 2011. Low dynamics, high longevity and persistence of sessile structural species dwelling on Mediterranean coralligenous outcrops S. Thrush [ed.]. PLoS ONE 6: e23744. doi:10.1371/journal.pone.0023744

Thorel, M., P. Claquin, M. Schapira, and others. 2017. Nutrient ratios influence variability in Pseudo-nitzschia species diversity and particulate domoic acid production in the Bay of Seine (France). Harmful Algae 68: 192-205. doi:10.1016/j.hal.2017.07.005 
806 Tréguer, P. J., J. N. Sutton, M. Brzezinski, and others. 2021. Reviews and syntheses: The

807 biogeochemical cycle of silicon in the modern ocean. Biogeosciences 18: 1269-1289.

808 doi:10.5194/bg-18-1269-2021

809 Van Soest, R. W. M., N. Boury-Esnault, J. Vacelet, and others. 2012. Global diversity of sponges

810 (Porifera). PLOS ONE 7: e35105. doi:10.1371/journal.pone.0035105

811 
812 Table 3. Summary of biogenic silica (bSi) standing stock in the sponge assemblages of the Bay of Brest (France). Average ( \pm SD) silica

813 content per unit of volume of living sponge tissue $\left(\mathrm{mg} \mathrm{bSi} \mathrm{mL}^{-1}\right)$ of each siliceous sponge species and average $( \pm \mathrm{SD})$ sponge $\mathrm{Si}$ stock per

814 square meter (mg Si $\left.\mathrm{m}^{-2}\right)$ in each habitat (RI, rocky intertidal; RS, rocky subtidal; MB, maerl beds; SM, shallow mud; HS, heterogeneous

815 sediments; CS, circalittoral coarse sediments) and for the total ecosystem of the Bay of Brest.

\begin{tabular}{|c|c|c|c|c|c|c|c|c|c|c|c|c|c|c|}
\hline \multirow[b]{4}{*}{ Sponge species } & & & \multicolumn{12}{|c|}{ Sponge contribution to the BSi standing stock (mg Si m${ }^{-2}$ ) } \\
\hline & \multirow{2}{*}{\multicolumn{2}{|c|}{$\begin{array}{c}\text { BSi content } \\
\left(\mathrm{mg} \mathrm{BSi} \mathrm{mL}^{-1}\right) \\
\end{array}$}} & \multicolumn{12}{|c|}{ Sponge contribution to the BSi standing stock $\left(\mathrm{mg} \mathrm{Si} \mathrm{m}^{-2}\right)$} \\
\hline & & & \multicolumn{2}{|c|}{ RI } & \multicolumn{2}{|c|}{$\mathrm{RS}$} & \multicolumn{2}{|c|}{ MB } & \multicolumn{2}{|c|}{ SM } & \multicolumn{2}{|c|}{ HS } & \multicolumn{2}{|c|}{$\mathrm{CS}$} \\
\hline & Mean & SD & Mean & SD & Mean & SD & Mean & SD & Mean & SD & Mean & $\mathrm{SD}$ & Mean & SD \\
\hline Amphilectus fucorum & 36.13 & 4.79 & & & 222.88 & 655.79 & 27.59 & 124.16 & & & 3.17 & 13.25 & 5.31 & 25.44 \\
\hline Antho inconstans & 33.27 & 4.25 & & & 101.84 & 567.05 & & & & & & & & \\
\hline Biemna variantia & 45.38 & 4.86 & & & 4.79 & 26.67 & & & & & & & & \\
\hline Bubaris vermiculata & 96.21 & 11.21 & & & & & & & & & & & 6.77 & 24.33 \\
\hline Chalinula cf. limbata & 43.92 & 6.96 & & & 31.79 & 177.00 & & & & & & & & \\
\hline Ciocalypta penicillus & 103.61 & 0.39 & & & 374.14 & $1,456.86$ & & & & & & & & \\
\hline Clathria strepsitoxa & 29.78 & 2.89 & & & 194.81 & 519.89 & & & & & 0.77 & 4.64 & 0.76 & 2.39 \\
\hline Cliona celata & 85.58 & 7.24 & & & $134,576.89$ & $389,757.49$ & & & $2,961.26$ & $11,145.37$ & 1.11 & 6.67 & 64.09 & 134.54 \\
\hline Cliona lobata & 78.15 & 5.94 & & & & & & & & & & & 102.10 & 122.41 \\
\hline Halichondria bowerbanki & 58.33 & 1.83 & & & 7.92 & 32.41 & 116.13 & 724.07 & & & & & 0.28 & 0.96 \\
\hline Halichondria panicea & 55.40 & 11.30 & 134.18 & 337.69 & 60.07 & 197.04 & 268.83 & 677.52 & & & 1.56 & 4.75 & 3.97 & 14.96 \\
\hline Halichondria sp. & 71.38 & 0.77 & & & 434.84 & 949.91 & 73.18 & 336.72 & & & & & & \\
\hline Haliclona angulata & 39.55 & 6.92 & & & & & & & & & & & 25.17 & 69.19 \\
\hline Haliclona cinerea & 37.79 & 4.50 & & & 17.10 & 95.19 & 6.91 & 18.02 & & & 1.16 & 6.94 & 1.48 & 3.37 \\
\hline Haliclona fibulata & 53.64 & 6.23 & & & & & & & & & & & 132.65 & 386.64 \\
\hline Haliclona fistulosa & 52.52 & 21.55 & & & 24.29 & 135.26 & 18.65 & 116.43 & & & & & 11.64 & 55.80 \\
\hline Haliclona rosea & 32.94 & 5.41 & & & 13.16 & 45.12 & 116.88 & 253.13 & & & 20.32 & 115.42 & 1.97 & 6.53 \\
\hline Haliclona simulans & 74.95 & 16.47 & & & 554.65 & $1,613.25$ & 613.86 & $1,374.11$ & & & 152.11 & 411.44 & 57.56 & 150.02 \\
\hline Hemimycale columella & 49.41 & 7.03 & & & 621.31 & $1,625.25$ & 37.82 & 165.58 & & & 8.66 & 51.97 & 1.10 & 5.27 \\
\hline
\end{tabular}




\begin{tabular}{|c|c|c|c|c|c|c|c|c|c|c|c|c|c|c|}
\hline Hymedesmia cf. occulta & 35.99 & 6.52 & & & & & & & & & & & 0.88 & 3.20 \\
\hline Hymedesmia coriacea & 32.58 & 6.30 & & & 0.49 & 2.74 & 5.81 & 27.81 & & & & & 0.65 & 3.11 \\
\hline Hymedesmia jecusculum & 36.29 & 5.67 & & & 21.73 & 86.53 & & & & & & & & \\
\hline Hymedesmia lenta & 30.47 & $5.05)$ & & & 7.75 & 43.17 & & & & & & & 7.48 & 27.56 \\
\hline Hymeniacidon perlevis & 48.88 & 6.18 & $1,975.23$ & $2,898.50$ & 794.85 & $1,854.75$ & $3,968.75$ & $5,403.69$ & & & 596.50 & $1,273.29$ & 54.60 & 248.94 \\
\hline Iophon hyndmani & 42.56 & 3.16 & & & & & & & & & & & 5.36 & 16.97 \\
\hline Iophon nigricans & 43.77 & 2.11 & & & & & & & & & & & 200.99 & 905.76 \\
\hline Mycale contarenii & 62.69 & 7.71 & & & 86.50 & 222.88 & 20.88 & 91.83 & & & 117.22 & 594.43 & & \\
\hline Mycale macilenta & 52.87 & 5.32 & & & 795.91 & $2,050.78$ & 0.14 & 0.88 & & & 16.91 & 69.90 & 3.19 & 8.36 \\
\hline Myxilla fimbriata & 50.77 & 4.34 & & & 128.62 & 340.78 & & & & & & & 0.39 & 1.86 \\
\hline Myxilla rosacea & 42.64 & 4.02 & & & & & & & & & & & 0.15 & 0.73 \\
\hline Pachymatisma johnstonia & 116.70 & 22.01 & & & $3,918.18$ & $15,445.96$ & & & & & & & & \\
\hline Paratimea constellata & 66.94 & 4.07 & & & & & & & & & & & 0.44 & 1.83 \\
\hline Phorbas fictitius & 93.20 & 5.22 & & & 420.82 & $2,061.94$ & 497.65 & $1,419.77$ & & & & & & \\
\hline Phorbas plumosus & 40.95 & 15.92 & & & 122.27 & 649.18 & 52.54 & 160.68 & & & & & & \\
\hline Polymastia boletiformis & 58.91 & 11.51 & & & 58.63 & 326.44 & & & & & & & 0.29 & 1.38 \\
\hline Polymastia penicillus & 71.41 & 7.84 & 1.27 & 6.09 & 230.17 & $1,258.52$ & & & & & & & 0.10 & 0.46 \\
\hline Protosuberites cf. denhartogi & 57.84 & 4.85 & & & 77.23 & 287.25 & & & & & 0.56 & 3.38 & & \\
\hline Raspailia ramosa & 56.76 & 5.60 & & & & & & & & & & & 1.69 & 8.12 \\
\hline Spanioplon armaturum & 32.48 & 3.26 & & & 463.15 & 920.96 & & & & & & & 0.24 & 0.96 \\
\hline Stelligera stuposa & 44.70 & 3.04 & & & 76.69 & 238.29 & & & & & 0.58 & 3.48 & 0.74 & 3.48 \\
\hline Suberites ficus & 114.77 & 12.45 & & & & & 995.23 & $6,105.84$ & 582.80 & $1,801.65$ & $4,972.06$ & $20,926.78$ & & \\
\hline Suberites massa & 96.02 & 4.70 & & & & & 0.25 & 1.60 & & & & & & \\
\hline Tedania anhelans & 34.90 & 6.42 & & & & & 105.64 & 493.25 & & & & & 122.48 & 266.90 \\
\hline Tethya citrina & 145.57 & 14.17 & $2,166.28$ & $3,780.43$ & $5,623.00$ & $15,889.11$ & $3,103.96$ & $5,192.50$ & & & $1,743.08$ & $3,022.67$ & 76.76 & 150.91 \\
\hline Timea crassa & 93.89 & 4.14 & & & & & & & & & 101.31 & 449.00 & 161.92 & 608.25 \\
\hline Total & 59.61 & 27.07 & $4,283.08$ & $4,191.32$ & $151,079.97$ & $387,576.21$ & $10,035.84$ & $10,742.40$ & $3,544.06$ & $11,126.45$ & $7,737.09$ & $20,560.60$ & 794.06 & $1,392.12$ \\
\hline
\end{tabular}




\section{Supplemental Information}

Supplementary Table 1 . Average concentration $( \pm \mathrm{SD})$ of dissolved silicon $\left(\mu \mathrm{mol} \mathrm{Si} \mathrm{L}^{-1}\right)$ at the bottom waters of the Bay of Brest. Data come from the Lanvéoc long-term survey series $\left(48.295777^{\circ} \mathrm{N}, 4.454758^{\circ} \mathrm{W}\right)$, which sampled bottom water with a $1 \mathrm{~L}$ syringe manually by scientific divers just over seabed every two weeks at high tide. Data integrated dissolved silicon concentrations from the last decade (2012-2021).

\begin{tabular}{|c|c|c|}
\hline \multirow[b]{2}{*}{ Month } & \multicolumn{2}{|c|}{ Dissolved Si concentration } \\
\hline & AVRG & SD \\
\hline Jan & 11.03 & 2.79 \\
\hline Feb & 13.28 & 5.68 \\
\hline Mar & 8.89 & 5.77 \\
\hline Apr & 2.44 & 2.20 \\
\hline May & 3.60 & 4.25 \\
\hline Jun & 2.44 & 1.22 \\
\hline Jul & 2.10 & 0.93 \\
\hline Aug & 2.83 & 0.55 \\
\hline Sep & 4.85 & 2.20 \\
\hline Oct & 8.35 & 5.08 \\
\hline Nov & 8.57 & 2.46 \\
\hline Dec & 10.13 & 2.36 \\
\hline
\end{tabular}


Supplementary Table 2. List of the sponge species of the Bay of Brest (France). Presence at each habitat is indicated. RI, rocky intertidal; RS, rocky subtidal; MB, maerl beds; SM, shallow mud; HS, heterogeneous sediments; CS, circalittoral coarse sediments.

\begin{tabular}{|c|c|c|c|c|c|c|}
\hline & & & Hab & bitat & & \\
\hline & $\mathbf{R I}$ & $\mathbf{R S}$ & MB & SM & HS & $\mathbf{C S}$ \\
\hline Class DEMOSPONGIAE & & & & & & \\
\hline Subclass HETEROSCLEROMORPHA & & & & & & \\
\hline Order AXINELLIDA & & & & & & \\
\hline Family RASPAILIIDAE & & & & & & \\
\hline Raspailia ramosa & & & & & & $\mathrm{X}$ \\
\hline Family STELLIGERIDAE & & & & & & \\
\hline Paratimea constellata & & & & & & $\mathrm{X}$ \\
\hline Stelligera stuposa & & $\mathrm{X}$ & & & $\mathrm{X}$ & $\mathrm{X}$ \\
\hline Order BIEMNIDA & & & & & & \\
\hline Family BIEMNIDAE & & & & & & \\
\hline Biemna variantia & & $\mathrm{X}$ & & & & \\
\hline Order BUBARIDA & & & & & & \\
\hline Family BUBARIDAE & & & & & & \\
\hline Bubaris vermiculata & & & & & & $\mathrm{X}$ \\
\hline Order CLIONAIDA & & & & & & \\
\hline Family CLIONAIDAE & & & & & & \\
\hline Cliona celata & & $\mathrm{X}$ & & $\mathrm{X}$ & $\mathrm{X}$ & $\mathrm{X}$ \\
\hline Cliona lobata & & & & & & $\mathrm{X}$ \\
\hline Order HAPLOSCLERIDA & & & & & & \\
\hline Family CHALINIDAE & & & & & & \\
\hline Chalinula cf. limbata & & $\mathrm{X}$ & & & & \\
\hline Haliclona angulata & & & & & & $\mathrm{X}$ \\
\hline Haliclona cinerea & & $\mathrm{X}$ & $\mathrm{X}$ & & $\mathrm{X}$ & $\mathrm{X}$ \\
\hline Haliclona fibulata & & & & & & $X$ \\
\hline Haliclona fistulosa & & $\mathrm{X}$ & $\mathrm{X}$ & & & $\mathrm{X}$ \\
\hline Haliclona rosea & & $\mathrm{X}$ & $\mathrm{X}$ & & $\mathrm{X}$ & $\mathrm{X}$ \\
\hline Haliclona simulans & & $X$ & $\mathrm{X}$ & & $\mathrm{X}$ & $\mathrm{X}$ \\
\hline Order POECILOSCLERIDA & & & & & & \\
\hline Family ACARNIDAE & & & & & & \\
\hline Iophon hyndmani & & & & & & $\mathrm{X}$ \\
\hline Iophon nigricans & & & & & & $X$ \\
\hline Family ESPERIOPSIDAE & & & & & & \\
\hline Amphilectus fucorum & & $\mathrm{X}$ & $\mathrm{X}$ & & $\mathrm{X}$ & $\mathrm{X}$ \\
\hline
\end{tabular}


Table S2. (Continued)

\begin{tabular}{|c|c|c|c|c|c|c|}
\hline & \multicolumn{6}{|c|}{ Habitat } \\
\hline & $\mathbf{R I}$ & $\mathbf{R S}$ & MB & SM & HS & CS \\
\hline \multicolumn{7}{|l|}{ Family HYMEDESMIIDAE } \\
\hline Hemimycale columella & & $\mathrm{X}$ & $\mathrm{X}$ & & $X$ & $\mathrm{X}$ \\
\hline Hymedesmia cf. occulta & & & & & & $X$ \\
\hline Hymedesmia coriacea & & $\mathrm{X}$ & $\mathrm{X}$ & & & $\mathrm{X}$ \\
\hline Hymedesmia jecusculum & & $\mathrm{X}$ & & & & \\
\hline Hymedesmia lenta & & $\mathrm{X}$ & & & & $X$ \\
\hline Phorbas fictitius & & $\mathrm{X}$ & $\mathrm{X}$ & & & \\
\hline Phorbas plumosus & & $\mathrm{X}$ & $\mathrm{X}$ & & & \\
\hline Spanioplon armaturum & & $\mathrm{X}$ & & & & $\mathrm{X}$ \\
\hline \multicolumn{7}{|l|}{ Family MICROCIONIDAE } \\
\hline Antho inconstans & & $\mathrm{X}$ & & & & \\
\hline Clathria strepsitoxa & & $\mathrm{X}$ & & & $\mathrm{X}$ & $X$ \\
\hline \multicolumn{7}{|l|}{ Family MYCALIDAE } \\
\hline Mycale contarenii & & $\mathrm{X}$ & $\mathrm{X}$ & & $\mathrm{X}$ & \\
\hline Mycale macilenta & & $\mathrm{X}$ & $\mathrm{X}$ & & $\mathrm{X}$ & $\mathrm{X}$ \\
\hline \multicolumn{7}{|l|}{ Family MYXILLIDAE } \\
\hline Myxilla fimbriata & & $\mathrm{X}$ & & & & $X$ \\
\hline Myxilla rosacea & & & & & & $X$ \\
\hline \multicolumn{7}{|l|}{ Family TEDANIIDAE } \\
\hline Tedania anhelans & & & $X$ & & & $X$ \\
\hline \multicolumn{7}{|l|}{ Order POLYMASTIIDA } \\
\hline \multicolumn{7}{|l|}{ Family POLYMASTIIDAE } \\
\hline Polymastia boletiformis & & $\mathrm{X}$ & & & & $\mathrm{X}$ \\
\hline Polymastia penicillus & $X$ & $\mathrm{X}$ & & & & $\mathrm{X}$ \\
\hline \multicolumn{7}{|l|}{ Order SUBERITIDA } \\
\hline \multicolumn{7}{|l|}{ Family HALICHONDRIIDAE } \\
\hline Ciocalypta penicillus & & $X$ & & & & \\
\hline Halichondria bowerbanki & & $X$ & $\mathrm{X}$ & & & $\mathrm{X}$ \\
\hline Halichondria panicea & $\mathrm{X}$ & $\mathrm{X}$ & $\mathrm{X}$ & & $\mathrm{X}$ & $\mathrm{X}$ \\
\hline Halichondria sp. & & $\mathrm{X}$ & $\mathrm{X}$ & & & \\
\hline Hymeniacidon perlevis & $\mathrm{X}$ & $X$ & $\mathrm{X}$ & & $\mathrm{X}$ & $\mathrm{X}$ \\
\hline \multicolumn{7}{|l|}{ Family SUBERITIDAE } \\
\hline Protosuberites cf. denhartogi & & $\mathrm{X}$ & & & $\mathrm{X}$ & \\
\hline Suberites ficus & & & $\mathrm{X}$ & $\mathrm{X}$ & $X$ & \\
\hline Suberites massa & & & $\mathrm{X}$ & & & \\
\hline
\end{tabular}


Table S2. (Continued)

\begin{tabular}{|c|c|c|c|c|c|c|}
\hline & \multicolumn{6}{|c|}{ Habitat } \\
\hline & $\mathbf{R I}$ & $\mathbf{R S}$ & MB & SM & HS & CS \\
\hline \multicolumn{7}{|l|}{ Order TETHYIDA } \\
\hline \multicolumn{7}{|l|}{ Family TETHYIDAE } \\
\hline Tethya citrina & $X$ & $X$ & $\mathrm{X}$ & & $\mathrm{X}$ & $\mathrm{X}$ \\
\hline \multicolumn{7}{|l|}{ Family TIMEIDAE } \\
\hline Timea crassa & & & & & $X$ & $\mathrm{X}$ \\
\hline \multicolumn{7}{|l|}{ Order TETRACTINELLIDA } \\
\hline \multicolumn{7}{|l|}{ Family GEODIIDAE } \\
\hline Pachymatisma johnstonia & & $\mathrm{X}$ & & & & \\
\hline \multicolumn{7}{|l|}{ Subclass KERATOSA } \\
\hline \multicolumn{7}{|l|}{ Order DENDROCERATIDA } \\
\hline \multicolumn{7}{|l|}{ Family DARWINELLIDAE } \\
\hline Aplysilla rosea & & $X$ & $\mathrm{X}$ & & $X$ & \\
\hline Aplysilla sulfurea & & $\mathrm{X}$ & $\mathrm{X}$ & & & \\
\hline \multicolumn{7}{|l|}{ Order DICTYOCERATIDA } \\
\hline \multicolumn{7}{|l|}{ Family DYSIDEIDAE } \\
\hline Dysidea fragilis & & $X$ & $X$ & & & \\
\hline \multicolumn{7}{|l|}{ Family THORECTIDAE } \\
\hline Hyrtios sp. & & & $X$ & & & \\
\hline \multicolumn{7}{|l|}{ Order DENDROCERATIDA } \\
\hline \multicolumn{7}{|l|}{ Family DICTYODENDRILLIDAE } \\
\hline Spongionella cf. pulchella & & $\mathrm{X}$ & & & & \\
\hline \multicolumn{7}{|l|}{ Subclass VERONGIMORPHA } \\
\hline \multicolumn{7}{|l|}{ Order CHONDRILLIDA } \\
\hline \multicolumn{7}{|l|}{ Family HALISARCIDAE } \\
\hline Halisarca dujardinii & & & & & & $X$ \\
\hline \multicolumn{7}{|l|}{ Class CALCAREA } \\
\hline \multicolumn{7}{|l|}{ Subclass CALCARONEA } \\
\hline \multicolumn{7}{|l|}{ Order LEUCOSOLENIDA } \\
\hline \multicolumn{7}{|l|}{ Family SYCETTIDAE } \\
\hline Sycon ciliatum & & $\mathrm{X}$ & $\mathrm{X}$ & & & \\
\hline \multicolumn{7}{|l|}{ Subclass CALCINEA } \\
\hline \multicolumn{7}{|l|}{ Order CLATHRINIDA } \\
\hline \multicolumn{7}{|l|}{ Family CLATHRINIDAE } \\
\hline Clathrina cf. coriacea & & & $\mathrm{X}$ & & & \\
\hline
\end{tabular}

